\title{
The Role of Floods in Particulate Organic Matter Dynamics of a Southern Appalachian River/Floodplain Ecosystem
}

\author{
By \\ Matthew A. Neatrour \\ Thesis submitted to the Faculty of the \\ Virginia Polytechnic Institute and State University \\ in partial fulfillment of the requirements for the degree of \\ Master of Science \\ in \\ Biology \\ APPROVED:
}

J. R. Webster, Chairman

E. F. Benfield

R. H. Jones

August 20, 1999

Blacksburg, Virginia 


\title{
The Role of Floods in Particulate Organic Matter Dynamics of a Southern Appalachian River/Floodplain Ecosystem
}

\author{
By \\ Matthew A. Neatrour \\ J. R. Webster \\ Chairman \\ Biology
}

\section{Abstract}

I investigated the role of a flood in particulate organic matter (POM) dynamics of the Little Tennessee river/floodplain ecosystem in western North Carolina, USA. I measured litter inputs, leaf breakdown, floodplain litter, and aboveground herbaceous net primary production at 12 sites. Annual litter inputs (274-625 $\left.\mathrm{g} \mathrm{m}^{-2} \mathrm{y}^{-1}\right)$ were typical of a temperate deciduous forest, but lower than other floodplain forests in the eastern United States. Mean aboveground herbaceous net primary production ranged from $61-439 \mathrm{~g} \mathrm{~m}^{-2}$ $\mathrm{y}^{-1}$ and leaf breakdown rates of 4 tree species ranged from $0.001-0.010 \mathrm{~d}^{-1}$. Following a flood on 8 January 1998, sites were separated into three inundation classes: inundated, partially-inundated, and non-inundated. Sites inundated by a January flood had significantly less forest floor leaf litter and coarse woody debris after the flood. There was no significant change at the partially-inundated or non-inundated sites. In addition, there was no significant difference in herbaceous material between pre- and post-flood collections for any inundation classes. Litter input, leaf breakdown, and floodplain litter standing crop data suggest that flood entrainment of POM from the floodplain of Little Tennessee River is a source of POM to the active channel. The impact of floods on the floodplain POM dynamics, however, is highly dependent on the time of year and magnitude of the flood, and on the structure of floodplain tree assemblages, which is strongly influenced by anthropogenic land use. Compared to direct litterfall and instream primary production, the floodplain may be a small annual source of POM for the river. 


\section{Acknowledgements}

I would like to thank Dr. Jack Webster for his assistance throughout my graduate career and specifically his guidance on this project. Jack always directed me away from examining extraneous details, keeping me close to the main story of my project. I would also like to thank Dr. Fred Benfield for his practical, down-to-earth advice on this project. Dr. Bob Jones gave plenty of helpful advice on analyzing tree assemblages and provided much needed taxonomic information on trees and shrubs of western North Carolina. Dr. Maury Valett helped me analyze my data, allowing me to think about my project in different ways, and Dr. Jeff Birch assisted in my statistical analysis.

My thanks to all the landowners who allowed me to place littertraps on their property. I would like to thank all the people who assisted in field data collection in western North Carolina. I am also grateful for all the lab help provided by an army of undergraduates. I don't think I would have been able to finish without you. I really appreciate the assistance. Financial assistance for this project was provided by a Coweeta LTER-NSF grant, the Virginia Tech Graduate Assembly, and the Virginia Tech Biology Department. Final thanks must also go to my parents, Dave and Donna Neatrour, who have been supportive throughout my graduate career and of my career choice. 


\section{Table of Contents}

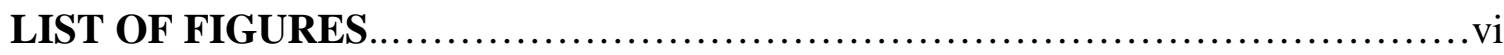

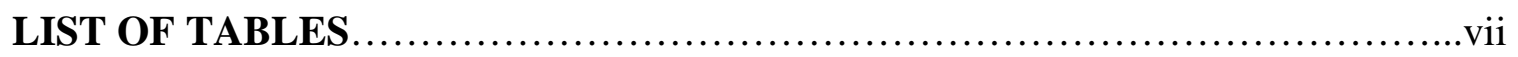

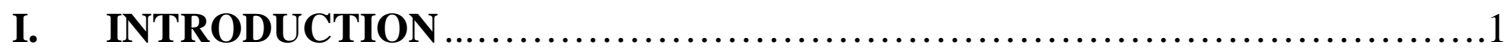

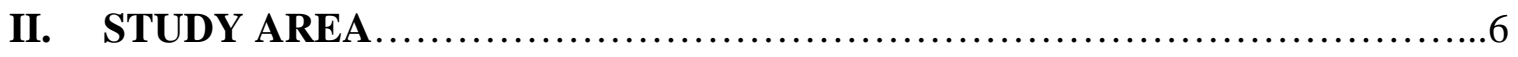

III. METHODS

A. Litter Inputs to the Floodplain .................................... 13

B. Herbaceous Aboveground Net Primary Production ........................ 14

C. Leaf Breakdown ................................................14

D. Floodplain Litter .............................................. 15

E. Floodplain Litter Computer Model ................................... 16

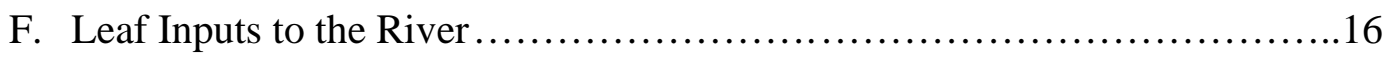

G. Tree Assemblages ............................................... 18

H. Statistical Analysis............................................. 18

\section{RESULTS}

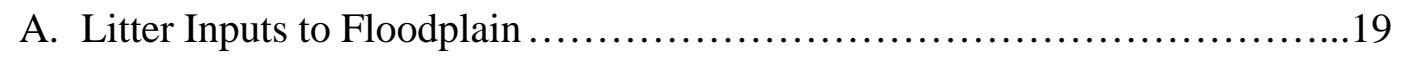

B. Herbaceous Aboveground Net Primary Production .......................24

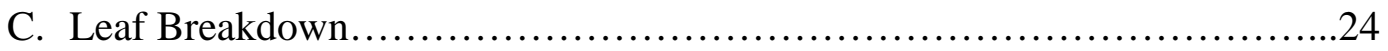

D. Floodplain Litter ............................................... 28

E. Floodplain Litter Computer Model ...................................35

F. Leaf Inputs to the River ....................................... 35

G. Tree Assemblages ............................................. 39 


\section{DISCUSSION}

A. Floodplain Particulate Organic Matter Dynamics .........................47

B. Flood Effects on POM Dynamics ...................................50

C. Leaf Inputs to the River ............................................54

D. Floodplain Tree Assemblages and POM Dynamics ........................56

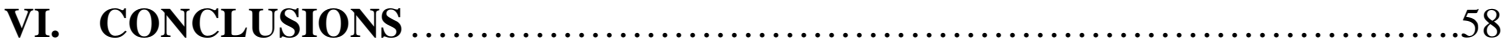

VII. LITERATURE CITED....................................................

\section{APPENDICES}

A. Leaf Inputs by Species to the Floodplain...............................66

B. Tree Importance on the Floodplain..................................68

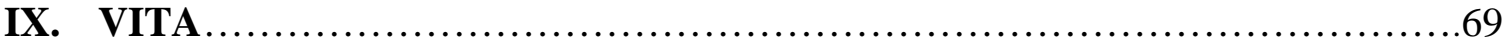




\section{List of Figures}

Figure 1: Conceptual model of floodplain POM dynamics ....................... 5

Figure 2: Site locations along the Little Tennessee River $\ldots \ldots \ldots \ldots \ldots \ldots \ldots \ldots \ldots \ldots$

Figure 3: Hydrograph of the Little Tennessee River ........................... 10

Figure 4: Annual peakflow of Little Tennessee River (1945-1998)............... 12

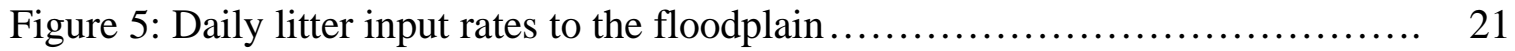

Figure 6: Daily leaffall rates of four common floodplain species .................. 23

Figure 7: Herbaceous ANPP as a function of leaffall.......................... 26

Figure 8: Leaf breakdown of four common floodplain species................... 27

Figure 9: Leaf breakdown of inundated and non-inundated leaf packs............. 29

Figure 10: Pre- and post-flood FPL of three inundation levels ................... 34

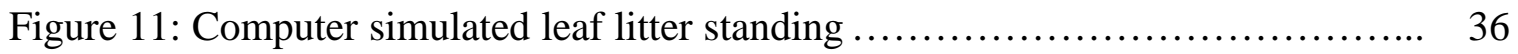

Figure 12: Correspondence analysis of floodplain tree species................... 40

Figure 13: Tree species composition based on basal area and number of trees ....... 43 


\section{List of Tables}

Table 1: General site descriptions ....................................... 8

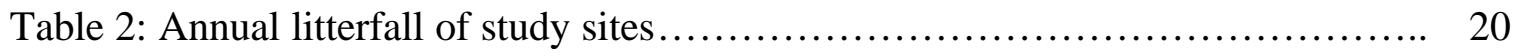

Table 3: Species composition of leaffall................................... 22

Table 4: Annual Herbaceous ANPP of study sites ............................. 25

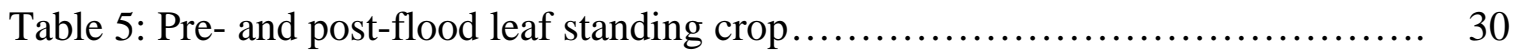

Table 6: Pre- and post-flood herbaceous standing crop...................... 31

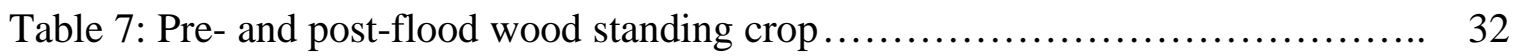

Table 8: Comparison of computer simulated and actual leaf standing crop of sites.... 37

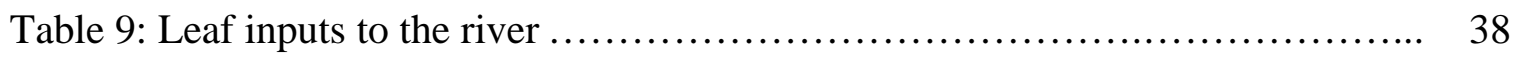

Table 10: Pearson correlations of species with ordination axes.................... 41

Table 11: Importance values of trees at study sites......................... 44

Table 12: Basal area, density, and importance values of floodplain tree species...... 45

Table 13: Litter inputs to river/floodplain ecosystems of eastern United States ........ 48

Table 14: Leaf breakdown coefficients of floodplain species in eastern United States. 51 


\section{Introduction}

My winding path now leads me again over the green fields into the meadows, sometimes visiting the decorated banks of the river, as it meanders through the meadows, or boldly sweeps along the bases of the mountains, its surface receiving the images reflected from the flowery banks above.

William Bartram (1791) referring to the Tanase (Little Tennessee) River near Otto, North Carolina

Allochthonous particulate organic matter (POM) is a source of energy for stream ecosystems and forms a strong linkage between streams and their adjacent riparian areas. Allochthonous POM usually consists of wood and leaf litter from plants, but may also include fruits, flowers, seeds, and insect frass. In small headwater streams, allochthonous POM inputs often are the primary energy source (Fisher and Likens 1973, Cummins 1974) and may also be an important energy source for larger streams (Hill 1981, Cuffney 1988, Smock 1990). Consequently, the amount of allochthonous POM that a particular stream receives may regulate ecosystem structure and function. Thus, determining the amount of POM entering streams is important in developing organic energy budgets and understanding energy dynamics for most streams (Connors and Naiman 1984).

Floodplains are highly connected to river ecosystems via periodic flooding in which there is extensive exchange of organic and inorganic materials (Tockner et al. 1999). Thus, floodplains may influence river POM dynamics through the exchange of organic matter between the river and floodplain. Dunne and Leopold (1964) defined a floodplain as a strip of relatively flat land bordering a stream that overflows at times of high water. The floodplain is formed mainly by the lateral migration and overbank deposition of sediments from the river. Over time, the river moves laterally by erosion at the one bank and deposition at the other. The result is an adjoining flat area that is flooded at times of high discharge when water exceeds bankfull stage, the stage when the surface level is the same as the floodplain. In most rivers, the recurrence interval of 
bankfull flow is about 1.5 years, but this number is highly variable from region to region (Dunne and Leopold 1964).

During floods, POM can enter rivers via entrainment from the floodplain. Thus, floodplains are temporary storage zones or sources of organic matter for river ecosystems (Mulholland 1981, Cuffney 1988, Smock 1990). Cuffney (1988) suggested that the floodplain of the Ogeechee River is major source of POM providing approximately 5.5 $\mathrm{kg} \mathrm{m}^{-2} \mathrm{y}^{-1}$ to the river. Smock (1990) found that litter on the floodplain is broken down into smaller particles and transported to the river during flooding in Colliers Creek, a blackwater stream in Virginia. Thus, the floodplain serves as the functional headwaters of these low gradient streams. In addition, Tockner et al. (1999) demonstrated that the floodplain of Danube River in Austria was a net exporter of POM to the river from a side channel on the floodplain. Shure et al. 1986, however, suggested that floodplains may be sinks or sources of organic matter depending on the annual hydroperiod. Cuffney (1988) proposed that a particular floodplain may be either a sink or source of POM depending on the flood regime, floodplain topography, and sediment load.

In addition to the exchange of POM during floods, riparian forests on floodplains can provide a direct source of POM to rivers. Small headwater streams often rely primarily on direct litterfall from riparian vegetation as a source of energy, but this is less apparent in larger streams because of their width. According to Vannote et al. (1980), average litter inputs per unit stream area should decrease as stream size increases. However, there is little evidence to support this observation in eastern deciduous forest mainly due to insufficient data for larger streams (Webster et al. 1995). Bott et al. (1985) showed no trends for the first three stream orders, but significantly reduced litter inputs by the fifth order. Connors and Naiman (1984) showed that allochthonous inputs of litter decreased with increasing stream order in a boreal watershed in Quebec. Benfield (1997), however, found that there was no significant relationship between litterfall and stream order after examining data for many different streams.

Vannote et al. (1980) also predicted that an increase in autochthonous production, such as primary production by periphyton or aquatic macrophytes, should accompany the reduction in relative allochthonous inputs. For instance, Lamberti and Steinman (1997) found that gross primary production (GPP) in medium sized streams was generally higher 
than in small streams. Since allochthonous organic matter forms the primary energy source in small streams, Vannote et al. (1980) predict that the primary production to respiration ratio $(\mathrm{P} / \mathrm{R})$ in small headwater streams should be low due to greater community respiration than primary production. However, as stream size increases the $\mathrm{P} / \mathrm{R}$ ratio should increase as primary production becomes more important than allochthonous organic matter as an immediate source of reduced carbon. Naiman (1984) showed that the P/R ratio was relatively low for first order streams but increased for fifth and sixth order streams. In addition, Webster and Meyer (1997) found that the P/R ratio increased with stream order in 35 streams in the United States. However, they found considerable scatter around this general trend. Other studies, on the other hand, have shown that the $\mathrm{P} / \mathrm{R}$ ratio in rivers may actually be comparable to headwater streams. For example, the P/R ratio in the Ogeechee River, a $6^{\text {th }}$ order blackwater stream in Georgia, was estimated to be 0.25 annually (Edwards and Meyer 1986, Edwards 1986).

The amount of allochthonous POM entering a stream may be more of a function of the amount of riparian vegetation adjacent to the stream channel on a local scale. Most rivers in the eastern United States have been affected by some degree of anthropogenic land use, which has resulted in the removal or reduction of riparian vegetation. This cannot only affect the amount of direct litterfall entering a river, but also the available pool of litter available for exchange between the floodplain and river during floods. Hill (1981) found that the input of allochthonous POM entering streams in the New River drainage in North Carolina and Virginia varied in different vegetation types. Litterfall was lowest in riparian areas with shrub vegetation and highest in areas of dense forest. Webster and Waide (1982) found that leaf inputs to Big Hurricane Branch, North Carolina, were reduced to less than $2 \%$ of previous levels following logging of the catchment. In general, anthropogenic land use typically results in a reduction of the biomass and a change in the taxonomic composition of adjacent riparian vegetation.

Previous work on floodplain-channel interactions has focused on coastal plain streams and large rivers. These streams generally flood regularly and have large extensive floodplains. For example, the Ogeechee River is flooded annually for 3-6 months and has a 1-2 km wide floodplain. Little work, however, has focused on determining the contribution of POM from the floodplains of mid-sized streams (5-7th 
order). Mid-sized streams share many characteristics with small and large streams, and thus may represent a transitional zone. Floodplains of mid-sized streams are much smaller and floods are more infrequent than streams in coastal plains such as the Ogeechee River or large rivers such as the Mississippi River. For example, the average width of the floodplain of the mid-sized New River was $20 \mathrm{~m}$ and floods occurred approximately $6.28 \mathrm{~d}$ annually from 1950 through 1980 (Hill 1981). It follows that POM inputs from the floodplain should not be as extensive as that of coastal plain streams and large rivers. Hill (1981) suggested that the floodplain contribution of POM to the New River in southwestern Virginia could, at maximum, be 1.5 times that of direct litter input. This assumes that there is no terrestrial decomposition, complete removal of litter from the floodplain, and no redeposition onto the floodplain when waters recede.

My objective was to determine how floods affect POM dynamics in a mid sizedriver/floodplain ecosystem . The specific objectives of this project were to: 1) measure floodplain POM dynamics in the absence of floods, 2) determine the net direction and importance of lateral POM transport between a mid-sized river and floodplain, and 3) examine how floodplain tree species assemblages affect floodplain/river POM dynamics. To address these objectives, I measured litter inputs (litterfall and herbaceous aboveground net primary production) and outputs (leaf breakdown), and POM standing crop (Figure 1). The exchange of POM between the floodplain and river was measured as the net change in standing crop before and after a flood. 



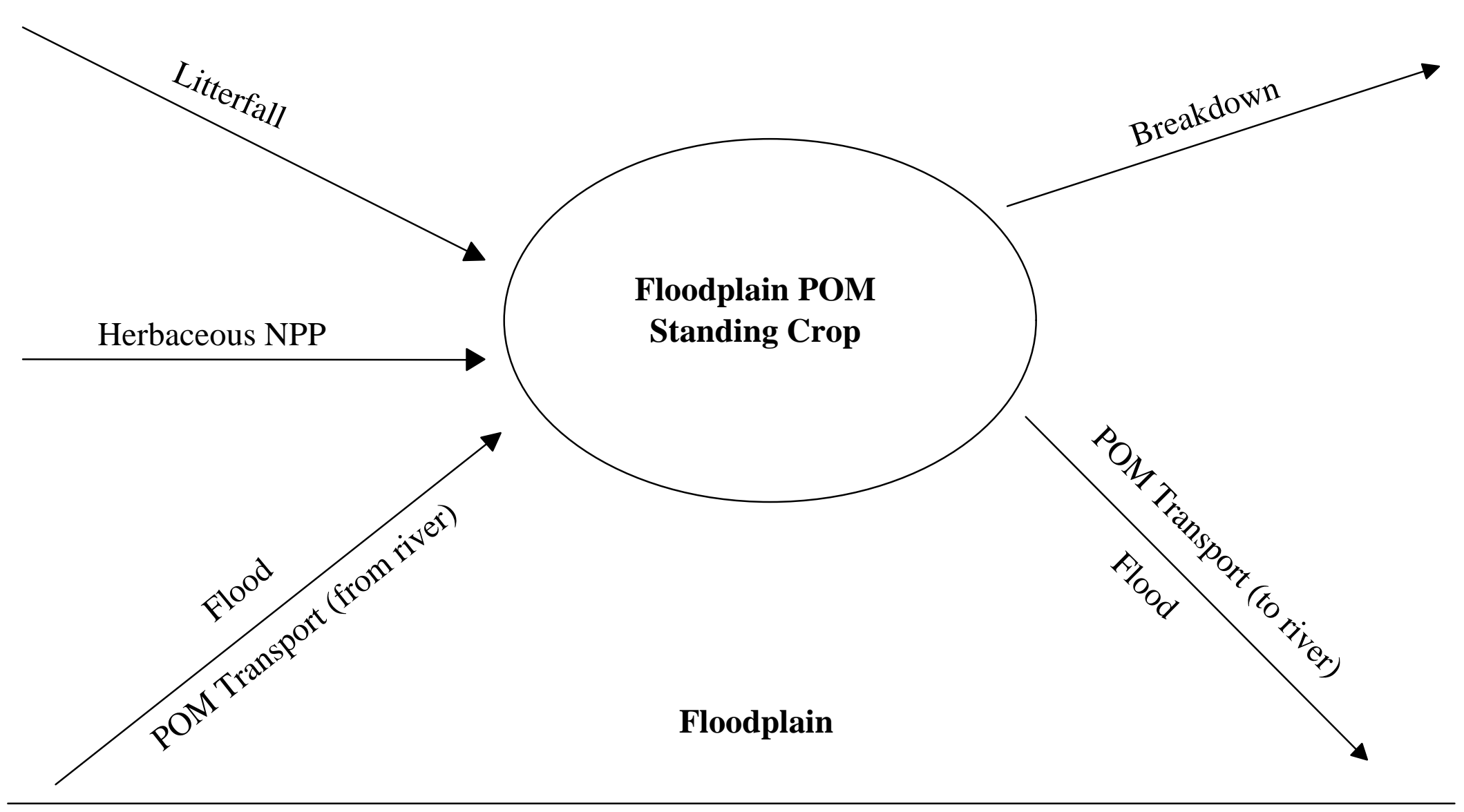

River Channel

Figure 1: Conceptual model of POM dynamics on floodplains. The box represents the store of POM on the floodplain and the arrows represent inputs to outputs from the POM store. 


\section{Study Area}

This study was conducted on the floodplain of the Little Tennessee River, Macon and Swain counties, western North Carolina. The Little Tennessee River drains a $10^{5}$-ha catchment area in the Nantahala Mountain chain of the Blue Ridge physiographic province in the southern Appalachian Mountains. This area is characterized by granitic parent materials resulting in naturally acidic water with low ionic concentrations (Swank and Waide 1988). Elevation of the river in the study area ranges from $537 \mathrm{~m}$ to $612 \mathrm{~m}$ and mean annual precipitation and air temperature for the region are $182.6 \mathrm{~cm}$ and $12.6^{\circ} \mathrm{C}$, respectively. The vegetation of the catchment was historically classified as an oak-chestnut forest association (Braun 1980). However, American chestnut (Castanea dentata) was extirpated due to the chestnut blight in the 1930s, and the vegetation can be now classified as an oak association (Vankat 1979).

Twelve sampling sites were established along a $65-\mathrm{km}$ reach of the Little Tennessee River beginning at the confluence with Coweeta Creek and ending at Fontana Reservoir (Figure 2). The study reach of the Little Tennessee River includes sixth and seventh order sections. The $6^{\text {th }}$ order upper Little Tennessee section begins at the confluence with Coweeta Creek and ends downstream at the confluence with the Cullasaja River, which nearly doubles the discharge of the river. The $7^{\text {th }}$ order lower Little Tennessee section begins at the confluence with the Cullasaja River and ends at Fontana Reservoir. Five sampling stations (U1-U5) were located on the upper Little Tennessee section and seven sampling stations (L1-L7) were located on the lower Little Tennessee section. General site characteristics are described in Table 1.

At baseflow, channel width of the Little Tennessee River ranges from $20 \mathrm{~m}$ to 110 $\mathrm{m}$, and water depth ranges between $0.5 \mathrm{~m}$ and $2 \mathrm{~m}$. In the upper $25 \mathrm{~km}$ of the river reach, streambed slope is minimal as the river meanders through an extensive alluvial valley. Runs and depositional areas of sandy substrata are common and the banks are high $(\sim 2$ $\mathrm{m}$ ) and eroded in this section of the river. The gradient increases in the lower $40 \mathrm{~km}$ of the river resulting in a constriction of the floodplain and a decrease in bank height $(\sim 1$ $\mathrm{m})$. In addition, runs and depositional areas are replaced by riffles running over bedrock substrata. 


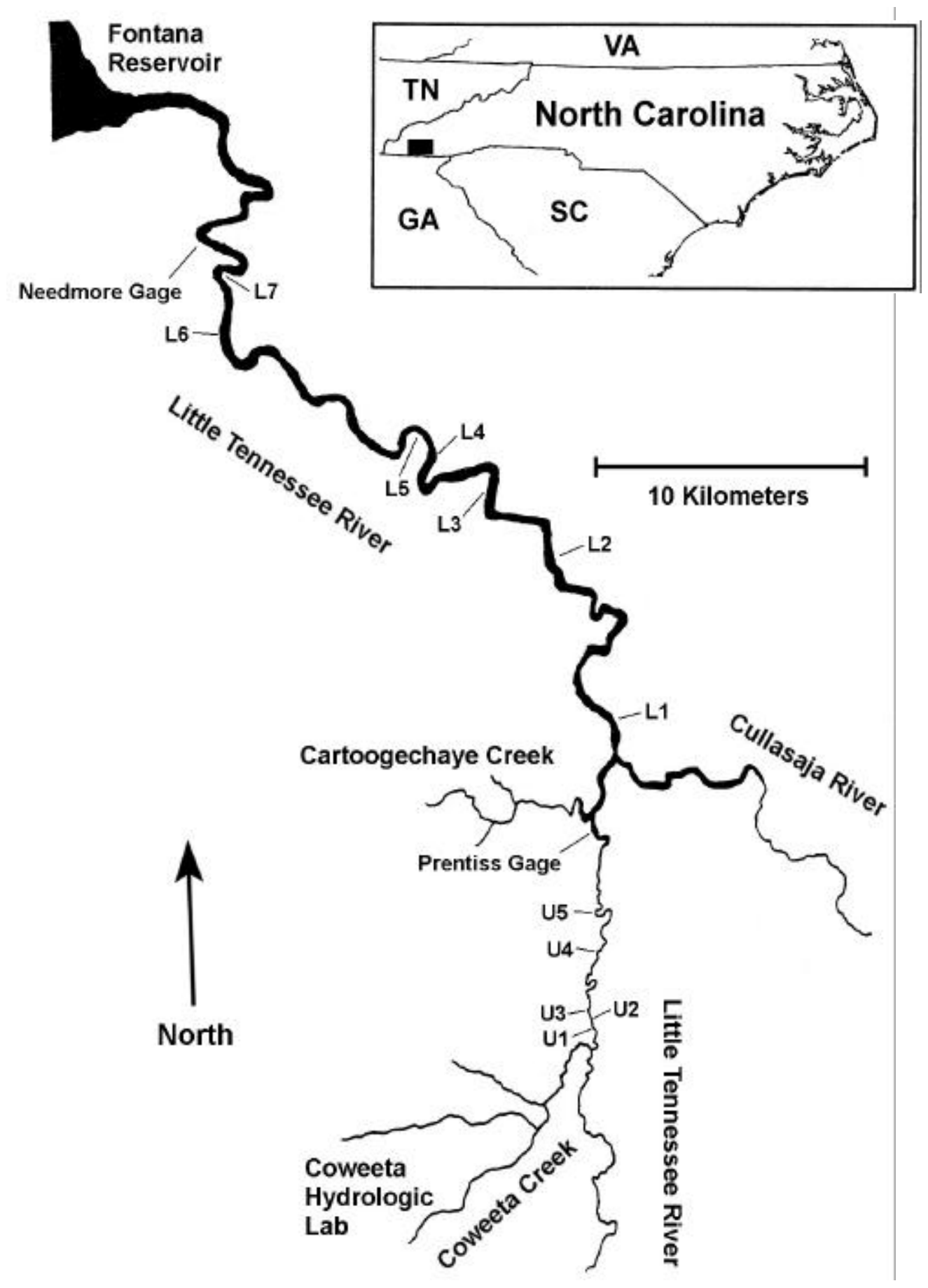

Figure 2: Site locations along the Little Tennessee River, NC. Sites and USGS gaging stations are indicated by lines. 
Table 1: Characteristics of the 12 sample sites along the Little Tennessee River, NC. River km are distances from the confluence with Coweeta Creek. Cleared land use includes all non-forested areas that are not agricultural, urban, or residential. All species were identified using Radford et al. (1968).

\begin{tabular}{|c|c|c|c|c|c|c|}
\hline Site & $\begin{array}{l}\text { River } \\
\text { km }\end{array}$ & $\begin{array}{l}\text { River } \\
\text { width } \\
\text { (m) }\end{array}$ & $\begin{array}{l}\text { Bank height } \\
\text { (m) }\end{array}$ & $\begin{array}{c}\text { Wooded riparian } \\
\text { width } \\
(\mathrm{m})\end{array}$ & $\begin{array}{l}\text { Land use beyond } \\
\text { wooded riparian }\end{array}$ & $\begin{array}{l}\text { Dominant tree } \\
\text { species }\end{array}$ \\
\hline $\mathrm{U} 1$ & 1.2 & 31 & 0.9 & $5-10$ & cleared & $\begin{array}{l}\text { Platanus occidentalis, Prunus serotina, } \\
\text { Juglans nigra, Carpinus caroliniana }\end{array}$ \\
\hline $\mathrm{U} 2$ & 1.7 & 22 & 1.9 & $<5$ & agriculture & $\begin{array}{c}\text { Juglans nigra, Carpinus caroliniana, } \\
\text { Prunus serotina }\end{array}$ \\
\hline U3 & 3.5 & 25 & 2.5 & $<5$ & cleared & $\begin{array}{c}\text { Juglans nigra, Carpinus caroliniana, } \\
\text { Prunus serotina }\end{array}$ \\
\hline U4 & 6.1 & 25 & 1.7 & $>30$ & forest & $\begin{array}{c}\text { Carpinus caroliniana, Platanus occidentalis, } \\
\text { Asimina triloba, Acer rubrum }\end{array}$ \\
\hline U5 & 9.1 & 21 & 3.1 & $5-10$ & cleared & $\begin{array}{c}\text { Juglans nigra, Prunus serotina, } \\
\text { Halesia carolina }\end{array}$ \\
\hline L1 & 18 & 38 & 0.1 & $20-30$ & urban & $\begin{array}{l}\text { Platanus occidentalis, Salix nigra, } \\
\text { Robinia pseudoacacia, Cornus sp. }\end{array}$ \\
\hline L2 & 28.8 & 80 & 1.7 & $>30$ & forest & $\begin{array}{l}\text { Carpinus caroliniana, Acer rubrum, } \\
\text { Liriodendron tulipfera, Halesia carolina }\end{array}$ \\
\hline L3 & 33.3 & 44 & 3.1 & $5-10$ & agriculture & $\begin{array}{l}\text { Lindera benzoin, Platanus occidentalis, } \\
\text { Halesia carolina, Juglans nigra }\end{array}$ \\
\hline L4 & 38.4 & 44 & 1.9 & $5-10$ & residential & Juglans nigra, Cornus sp. \\
\hline L5 & 40.4 & 55 & 1.5 & $>30$ & forest & $\begin{array}{c}\text { Carpinus caroliniana, Carya glabra, } \\
\text { Cornus florida }\end{array}$ \\
\hline L6 & 51.5 & 91 & 2.6 & $>30$ & forest & $\begin{array}{c}\text { Liriodendron tulipfera, Carpinus caroliniana, } \\
\text { Halesia carolina, Acer rubrum }\end{array}$ \\
\hline L7 & 53.3 & 78 & 1.4 & $10-20$ & agriculture & $\begin{array}{l}\text { Halesia carolina, Acer rubrum, } \\
\text { Juglans nigra, Cornus sp. }\end{array}$ \\
\hline
\end{tabular}


The Little Tennessee River is primarily bordered by a 5-10 m strip of wooded riparian vegetation. This small wooded riparian section, however, gradually becomes wider downstream $(\sim 40 \mathrm{~km})$. In general, the riparian area is $80 \%$ wooded in the first $5 \mathrm{~m}$ of floodplain adjacent to the river but only $44 \%$ in the second $5 \mathrm{~m}$. Dominant woody vegetation in the riparian strip along the Little Tennessee River consists of mixed deciduous species including sycamore (Platanus occidentalis), American hornbeam (Carpinus caroliniana), black walnut (Juglans nigra), and red maple (Acer rubrum).

Historically, anthropogenic land use disturbances were extensive in the Little Tennessee River catchment. In 1950, 19\% of the catchment was cleared primarily for agriculture (e.g. row crop and cattle). This catchment, however, has largely reforested since 1950 and only 10\% was non-forested in 1990 (Wear and Bolstad 1998). Currently, there is still substantial agriculture in riparian areas adjacent to the Little Tennessee River, particularly in the upper reach that flows through the wide alluvial floodplain valley. In addition to agriculture, this reach of the Little Tennessee River is impacted by urbanization as the river flows through Franklin, NC, and there is a small hydroelectric dam north of Franklin. In contrast, the lower sections of the river mainly have forested riparian zones.

Discharge data of the Little Tennessee River were obtained for two gaging stations (Figure 2) at Prentiss (14 km) and Needmore (58 km). The Prentiss gage is located upstream of the confluence with the Cullasaja River and the Needmore gage is located downstream of the confluence with the Cullasaja River. During the course of the study, mean daily discharge ranged from 2 to $136 \mathrm{~m}^{3} / \mathrm{s}$ at Prentiss and 5 to $380 \mathrm{~m}^{3} / \mathrm{s}$ at Needmore. Mean discharge was $12 \mathrm{~m}^{3} / \mathrm{s}$ at Prentiss and $32 \mathrm{~m}^{3} / \mathrm{s}$ at Needmore. Summer baseflow conditions were approximately $4 \mathrm{~m}^{3} / \mathrm{s}$ at Prentiss and $11 \mathrm{~m}^{3} / \mathrm{s}$ at Needmore.

In general, the Little Tennessee River was flashy with several short peaks in discharge (Figure 3 ). These peaks were generally more frequent during the winter. On 8 Jan 98, the river flooded. This flood was a short pulse; the river flooded and receded within its banks in two days. The instantaneous discharge of the flood (recorded hourly by USGS) was $169 \mathrm{~m}^{3} / \mathrm{s}$ at Prentiss and $438 \mathrm{~m}^{3} / \mathrm{s}$ at Needmore which is $42 \mathrm{x}$ and $40 \mathrm{x}$ summer baseflow conditions, respectively. In a historical context, the flood of 1998 was rather large relative to past years (Figure 4). Of the years on record (1945-1998), seven 


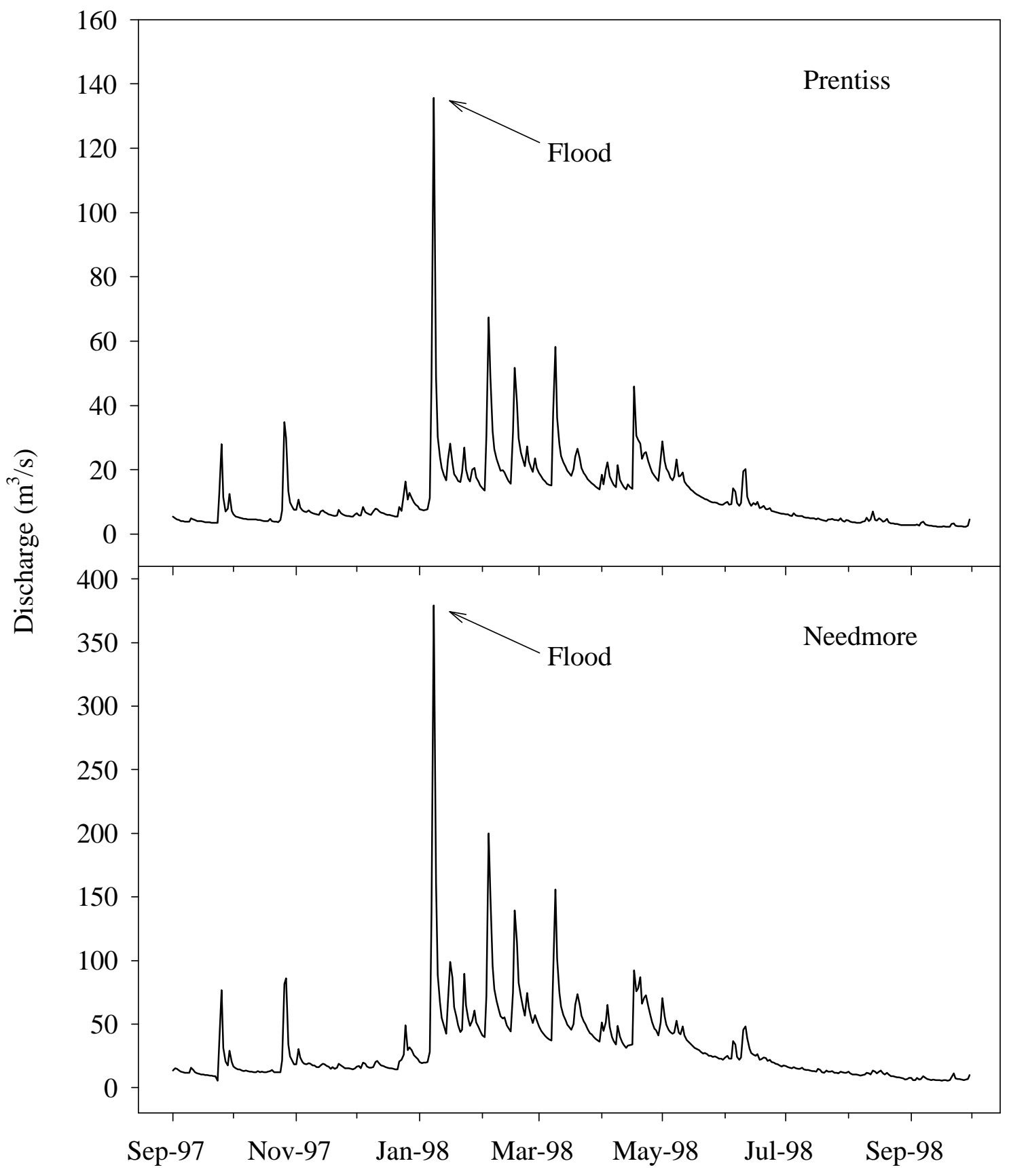

Figure 3: Little Tennessee River hydrograph at Prentiss and Needmore USGS gaging stations. The flood (8 Jan 98) is indicated by arrows on each hydrograph. 
annual peakflows were higher at Prentiss and only five annual peakflows were higher at Needmore. Flood frequency was also calculated for each gage (Dunne and Leopold 1978). The flood recurrence interval was $7.4 \mathrm{y}$ at Prentiss and $8.4 \mathrm{y}$ at Needmore. 


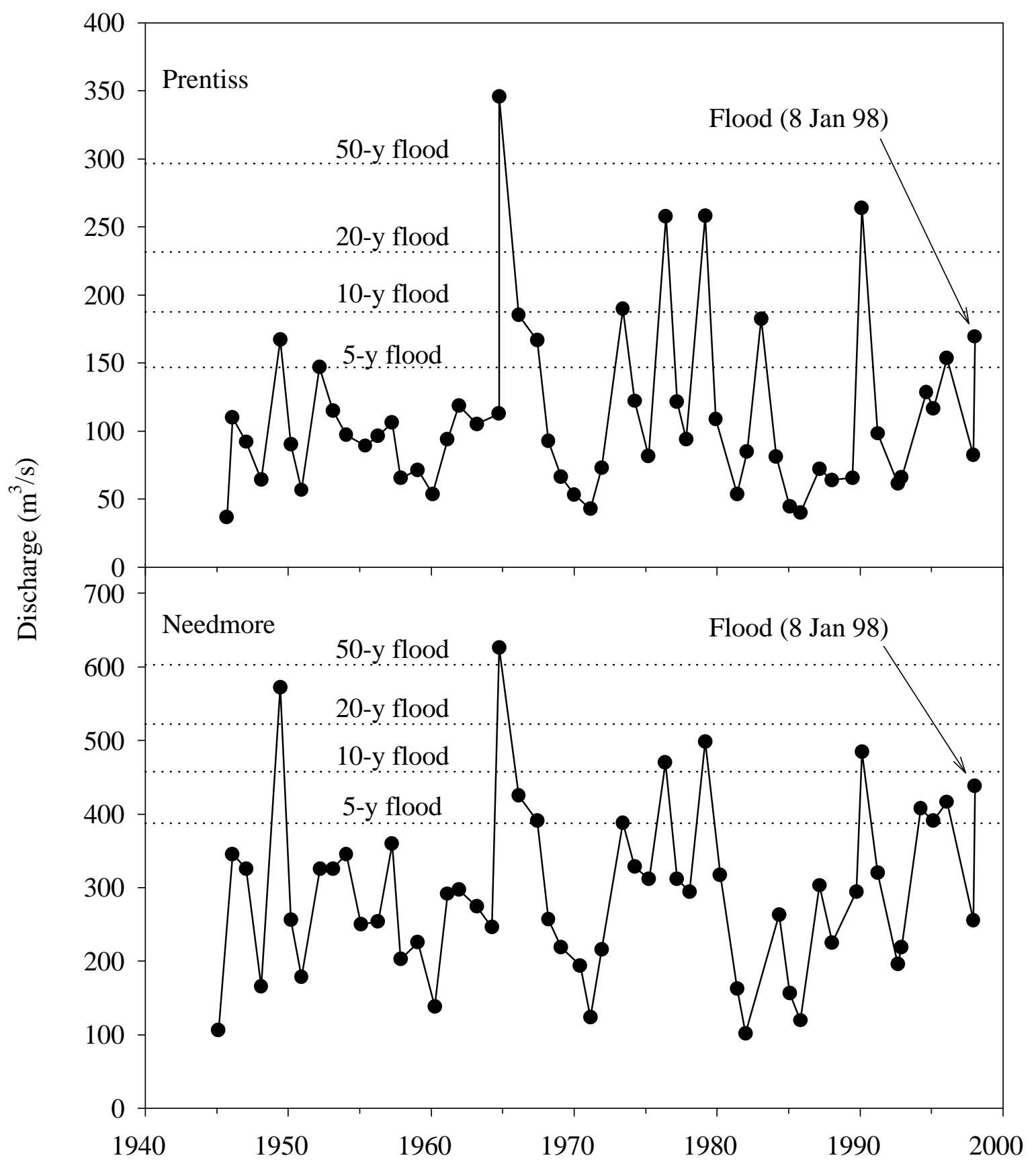

Figure 4: Annual peakflow discharge at Prentiss and Needmore USGS gaging stations. Arrows indicate the flood that occurred during the study year (8 Jan 98). Flood recurrence intervals for 5, 10, 20, and 50 y floods are indicated by lines. 


\section{Methods}

\section{Litter Inputs to the Floodplain}

Litter inputs were quantified using $1200.25-\mathrm{m}^{2}$ floodplain litter traps. Ten litter traps were placed at 2-m intervals along a transect parallel to the river channel at each of the 12 sites. Litter traps consisted of a $0.25-\mathrm{m}^{2}$ frame fitted with 1-mm mesh fiberglass screen and supported by three wooden stakes. Litter was removed from the traps bimonthly during times of peak leaf-fall (October-November) and monthly at other times of the year from September 1997 until September 1998. Litter from each trap was dried $\left(50^{\circ} \mathrm{C}, 2 \mathrm{~d}\right)$ and separated into leaves, wood, and miscellaneous litter (e.g., reproductive material). All leaves were sorted to species, weighed, recombined, ground, and subsampled. Wood and miscellaneous litter were weighed, ground, and subsampled. Subsamples were weighed, ashed $\left(550^{\circ} \mathrm{C}, 45 \mathrm{~min}\right)$, and reweighed to determine ash free dry mass (AFDM).

The flood of Jan 1998 affected litter traps at 8 of 12 sites. All traps were missing at two sites (U2 and L7) following the flood. These traps were not replaced. The flood did not remove litter traps at the other six sites affected by the flood. However, litter collected in January 1998 from these sites was discarded because it was impossible to determine whether the litter originated from litterfall or flood transport. In addition, litter traps were also missing at one site (L5) because of vandalism in March 1998 and were not replaced.

I estimated total annual leaffall for the three sites where litter traps were missing using the site with the closest cumulative leaffall total (reference site) at the time the traps were lost. I calculated annual leaffall of the estimated sites by multiplying annual leaffall of the reference site by the ratio of leaffall of the estimated site to the reference site at time of trap loss. Annual wood and miscellaneous inputs were estimated using a different method because these inputs were highly variable within and among sites, such that no sites were easily comparable throughout the study year. Thus, I estimated annual wood or miscellaneous inputs at sites with missing traps by multiplying the ratio of cumulative wood or miscellaneous material to cumulative leaffall at the time of trap loss by the estimated annual leaffall total for that site. 
I estimated leaffall for sites missing only the January collection period (18-19 Dec to $18 \mathrm{Jan}$ ), using an linear interpolation of log transformed leaffall rates of the previous period (23 Nov to 18-19 Dec) and following period (18 Jan to 14-15 Feb) to predict daily leaffall rates of the January collection period. These daily rates were summed to determine total leaffall of the January collection period. A linear interpolation of log transformed data was used because it provided the best fit for sites that were not affected by the flood. Wood and miscellaneous inputs were estimated using a similar technique except that I used a linear interpolation.

\section{Herbaceous Aboveground Net Primary Production}

Herbaceous aboveground net primary production (ANPP) was measured on the floodplain using clip plots. Herbaceous plants were collected from $100.25-\mathrm{m}^{2}$ plots in each site in August 1998. The plots were randomly placed on the floodplain no more than $10 \mathrm{~m}$ from the banks of the Little Tennessee River in an area either immediately upstream or downstream from the existing littertraps to avoid places where herbaceous plants had been previously trampled. Herbaceous plants were cut to ground level in each plot and air dried. In order to estimate annual ANPP, woody perennial grasses were removed from samples (Arundinaria gigantea), and the remaining plants were weighed and subsampled. Subsamples were ground, weighed, ashed, and reweighed to determine AFDM.

\section{Leaf Breakdown}

Leaf breakdown on the floodplain was measured using individual species leaf packs to facilitate species specific comparisons with other leaf breakdown studies conducted in stream ecosystems. Fifteen leaf packs of the two most common floodplain species, sycamore (Platanus occidentalis) and American hornbeam (Carpinus caroliniana), were placed on the floodplain at 8 of the 12 sites, and 15 leaf packs of two other common floodplain species, red maple (Acer rubrum) and black walnut (Juglans nigra), were placed at 3 sites. Leaf packs of a given species were placed at sites were that species was ubiquitous. Each leaf pack initially contained $8 \mathrm{~g}$ of leaf material. Three leaf packs of American hornbeam, black walnut, and red maple were retrieved at 1, 2, 4, 
6, and 7 mo intervals at each site, and three leaf packs of sycamore were collected at 1,2, 4, 7, and 9 mo intervals at each site. Leaves were washed, dried, weighed, ground, and subsampled. Subsamples were weighed, ashed, and reweighed to determine AFDM. For each species, an exponential rate of breakdown was determined from the negative slope of the log percentage AFDM remaining (y-axis) vs. the days of exposure (x-axis) (e.g. Benfield 1996).

I calculated an annual composite exponential rate of decomposition $(k)$ for each site by a weighted average calculation based on the \% species composition of leaffall at a given site. Decay rates of species not directly measured in the field were classified as either having medium or slow decomposition based on findings of Webster and Benfield (1986). I assigned leaves with medium breakdown rates a mean breakdown rate of American hornbeam, black walnut, and red maple; leaves with slow breakdown rates were given the same breakdown rate as sycamore.

\section{Floodplain Litter}

The standing crop of particulate organic matter (POM) on the floodplain was measured by collecting floodplain litter (FPL) from $200.05-\mathrm{m}^{2}$ plots at each site (240 total plots) in Dec 1997 (pre-flood) and Jan 1998 (post-flood). At five sites (U1, U4, U5, L2, and L7), post-flood FPL was distributed unevenly in debris piles. Debris piles within

a delineated $10 \times 100 \mathrm{~m}$ area were measured (length and width), and a $0.05-\mathrm{m}^{2}$ subsample from was removed from each pile. All litter was dried, weighed, ground, and subsampled. Subsamples were ashed and reweighed to determine AFDM.

Following the flood, sites were classed based on the amount of inundation in the sample collection area: inundated, partially-inundated, and non-inundated sites. Although the river exceeded its banks at partially-inundated sites, only part of the sampling area of post-flood sampling was inundated by the flood.

In order to determine whether the flood significantly affected FPL standing crop, I adjusted pre-flood leaves for leaffall and leaf breakdown in the interim between pre- and post-flood collections. Thus, I predicted what leaf litter should be on the date of postflood collection (30-31 January 1998) in the absence of a flood. Expected leaf inputs were added to pre-flood leaf litter and losses due to leaf breakdown were subtracted from 
pre-flood leaf litter. Leaf inputs were determined using a linear interpolation of log transformed leaffall rates as described earlier and leaf breakdown rates were determined using a winter breakdown rate for each site (December-February). Two sites (U2 and L7) were not corrected for leaf inputs because all littertraps were removed by the flood, thus there was no way to interpolate leaffall rates. In addition, pre-flood herbaceous and wood standing crops were not adjusted to the date of post-flood collection because breakdown of these litter types was not directly measured in the field. For all litter types, I adjusted post-flood FPL to reflect the presence of debris piles.

\section{Floodplain Litter Computer Model}

In order to determine importance of floods in floodplain POM dynamics, I constructed a linear, donor-controlled model consisting of one compartment using a computer program. In the absence of floods, the change in the leaf standing crop was the integration of the difference between the inputs (leaf inputs) and the outputs (breakdown):

$$
\frac{d L}{d t}=F_{L}-k_{L}(L)
$$

where $L$ is the standing crop of leaf litter on the floodplain floor, $t$ is time, $F_{L}$ is leaffall, $k_{L}$ is the composite leaf breakdown rate. Leaf inputs were made to fluctuate throughout the year using linear interpolations to estimate leaffall between collection periods. The model was run to steady state (annual leaf inputs = annual leaf outputs), and I compared the predicted steady state value of the model to the measured leaf litter standing crop of each site and inundation class.

\section{Leaf Inputs to the River}

Direct leaffall to the Little Tennessee River was calculated based on a model of litterfall into a lake (Gassith and Hasler 1976), which assumes a linear decline of leaffall with increasing distance from the river banks. The model predicts that litterfall decreases to zero at $10 \mathrm{~m}$ from the river banks by the following equation: 


$$
F_{w}=F_{b}-\left(\frac{F_{b}}{10} \bullet w\right)
$$

where $F_{b}$ is bank leaffall, $w$ is distance from the bank, and $F_{w}$ is leaffall at some distance $w$ from the banks. However, littertraps were placed approximately $2 \mathrm{~m}$ from the banks on the floodplain (i.e. $-2 \mathrm{~m}$ from the river banks) and the equation was modified so that to leaffall $\left(F_{w}\right)$ could be calculated at any distance from the littertraps:

$$
F_{w}=\frac{5}{6} F_{x}-\left(\frac{F_{x}}{12} \bullet w\right)
$$

where $F_{x}$ is leaffall at $-2 \mathrm{~m}$ from the river banks. From this equation, I calculated bank leaffall. Direct leaffall to the river was then determined by integrating equation 2 from 0 to $10 \mathrm{~m}$.:

$$
Z=\int_{0}^{10} F b+\left(\frac{F_{b}}{10} \bullet w\right) d w
$$

to yield:

$$
Z=5 F_{b}
$$

assuming $\mathrm{w}>10 \mathrm{~m}$ and riparian forest width $>20 \mathrm{~m}$ on each side, where $\mathrm{Z}$ is leaffall (in gAFDM per linear meter). $\mathrm{Z}$ was converted to direct leaffall in $\mathrm{gAFDM} / \mathrm{m}^{2}$ by multiplying by two, assuming that leaffall is equal on both sides of the river, and dividing by river width.

Flood inputs of leaves to the river were calculated assuming that $10 \mathrm{~m}$ of forested area on both sides of the river had been inundated. This was an overestimate in that $10 \mathrm{~m}$ on both sides of the river did not flood along the entire $65-\mathrm{km}$ study reach. In addition, in many cases, there were not $10 \mathrm{~m}$ of forested riparian vegetation on both sides of the river 
(Table 1). Flood input of leaves from the floodplain per $\mathrm{m}^{2}$ was multiplied by $20 \mathrm{~m}$ (10 $\mathrm{m}+10 \mathrm{~m}$ ) to determine total flood input in $\mathrm{gAFDM} / \mathrm{m}$. This value was then divided by the width of the river to yield flood inputs to the river in $\mathrm{gAFDM} / \mathrm{m}^{2}$.

\section{Tree Assemblages}

Floodplain tree species were surveyed in October 1998. A 20 x $100 \mathrm{~m}$ plot was delineated at each site and separated into two adjacent $10 \times 100 \mathrm{~m}$ plots. The first plot was immediately adjacent to the bank of the stream channel and second plot began $10 \mathrm{~m}$ from the bank. All trees greater than $2 \mathrm{~cm}$ DBH were identified and measured (DBH) within the two plots. Importance values (IV) of tree species were determined for each site and all sites combined. I calculated importance values based on density and basal area. (Curtis and McIntosh 1951).

\section{Statistical Analysis}

A general linear model with dummy variables was used to make pairwise comparisons between leaf breakdown rates of different leaf species or inundation classes. Alpha was adjusted according to the Bonferroni technique based on the number of pairwise comparisons (Sokal and Rohlf 1995).

A paired t-test was used to compare pre- and post-flood litter for different inundation classes: inundated $(n=8)$, partially-inundated $(n=2)$, and non-inundated ( $n=$ 2). However, partially-inundated and non-inundated classes had low replication of sites resulting in little power. Thus, in order to reduce the chances of a Type II error associated with low replication, the partially-inundated and non-inundated classes were combined $(n=4)$, and an additional paired t-test was run.

A correspondence analysis (reciprocal averaging ordination) was used to compare sites based on tree species composition. In addition, several biological variables at each site (litterfall, herbaceous NPP, total number of trees, and total tree basal area) were cross correlated with the each of the three axes created by the ordination to determine if these variables were related to floodplain tree assemblage. In addition, tree species were also cross correlated with each axis to determine which species were responsible for the differences among sites. 


\section{Results}

\section{Litter Inputs to the Floodplain}

Across all sites, litter inputs ranged from 274 to $625 \mathrm{gAFDM} \mathrm{m} \mathrm{y}^{-2}$ with a mean of $448 \mathrm{gAFDM} \mathrm{m}^{-2} \mathrm{y}^{-1}$ (Table 2). Of this amount, leaves constituted $383 \mathrm{gAFDM} \mathrm{m}^{-2} \mathrm{y}^{-1}$ (85\%), wood $45 \mathrm{gAFDM} \mathrm{m}^{-2} \mathrm{y}^{-1}(10 \%)$, and miscellaneous material $21 \mathrm{gAFDM} \mathrm{m}^{-2} \mathrm{y}^{-1}$ (5\%). Leaffall was closely related to the phenology of a temperate deciduous forest (Figure 5). There was an initial large increase in leaffall in autumn 1997; 73\% of all leaf inputs to the floodplain occurred by 18 Dec. Leaffall was low in the winter but was followed by an increase in late summer. In contrast, wood inputs were low during the fall and summer and highest during the winter; 55\% of inputs occurred from January to April (Figure 5). Miscellaneous material inputs (e.g., reproductive material) were initially high due to large inputs of nuts at a few sites, especially of black walnut and pignut hickory (Carya glabra), but decreased during winter (Figure 5). Miscellaneous material inputs were also high in the spring and early summer. This was mainly due to flowers, particularly of American hornbeam, and the fruit of black cherry (Prunus serotina) at site $\mathrm{U} 1$.

Thirty-seven species contributed leaves to the floodplain of the Little Tennessee River. The results presented in Table 3 summarize tree species contributing at least $2 \%$ of the total weight through 18 Dec 97. This was the latest date of litter collection at all sites and $73 \%$ of total leaffall occurred by this date. A complete list of species is presented in Appendix A. Sycamore and American hornbeam were common everywhere and contributed $31 \%$ of total leaffall during this time period. At a few sites, there were also large leaf inputs of black walnut and red maple and to lesser extent Carolina silverbell (Halesia carolina), yellow-poplar (Liriodendron tulipfera), and black cherry. In contrast, pignut hickory, black gum (Nyssa sylvatica), and white oak (Quercus alba) were confined to one or two sites where leaf inputs of these species were high.

There were also sizable inputs of unidentifiable leaf fragments at all sites.

Leaf abscission of species also occurred at slightly different times during fall. Daily leaffall rates of four common species used to measure leaf breakdown showed that black walnut fell earlier than the other three species (Figure 6). Although peak leaffall 
Table 2: Annual litterfall at 12 sites along the Little Tennessee River, NC. Values are means in $\mathrm{gAFDM} \mathrm{m} \mathrm{y}^{-2} \mathrm{y}^{-1}$ with standard deviation of sites in parentheses. Site L1 was used to estimate annual litterfall of sites L5 and L7, and site U3 was used to estimate annual litterfall of site U2.

\begin{tabular}{|c|c|c|c|c|}
\hline Site & Leaves & Wood & Miscellaneous & Total \\
\hline $\mathrm{U} 1^{\mathrm{b}}$ & 392 & 109 & 48 & 550 \\
\hline $\mathrm{U} 2^{\mathrm{a}}$ & 253 & 4 & 16 & 274 \\
\hline U3 & 209 & 8 & 17 & 233 \\
\hline $\mathrm{U} 4^{\mathrm{b}}$ & 422 & 113 & 29 & 564 \\
\hline U5 & 269 & 6 & 4 & 278 \\
\hline $\mathrm{L} 1^{\mathrm{b}}$ & 411 & 111 & 4 & 526 \\
\hline $\mathrm{L} 2^{\mathrm{b}}$ & 581 & 24 & 21 & 625 \\
\hline $\mathrm{L} 3^{\mathrm{b}}$ & 485 & 50 & 21 & 555 \\
\hline $\mathrm{L} 4^{\mathrm{b}}$ & 406 & 17 & 44 & 467 \\
\hline $\mathrm{L}^{\mathrm{a}}$ & 350 & 8 & 21 & 378 \\
\hline L6 & 455 & 67 & 10 & 532 \\
\hline $\mathrm{L} 7^{\mathrm{a}}$ & 361 & 25 & 13 & 399 \\
\hline Mean & $383(104)$ & $45(44)$ & $21(14)$ & 448 (132) \\
\hline$\%$ of total & 85 & 10 & 5 & \\
\hline
\end{tabular}

${ }^{a}$ sites with estimated annual litterfall

${ }^{\mathrm{b}}$ sites with estimated January litterfall 


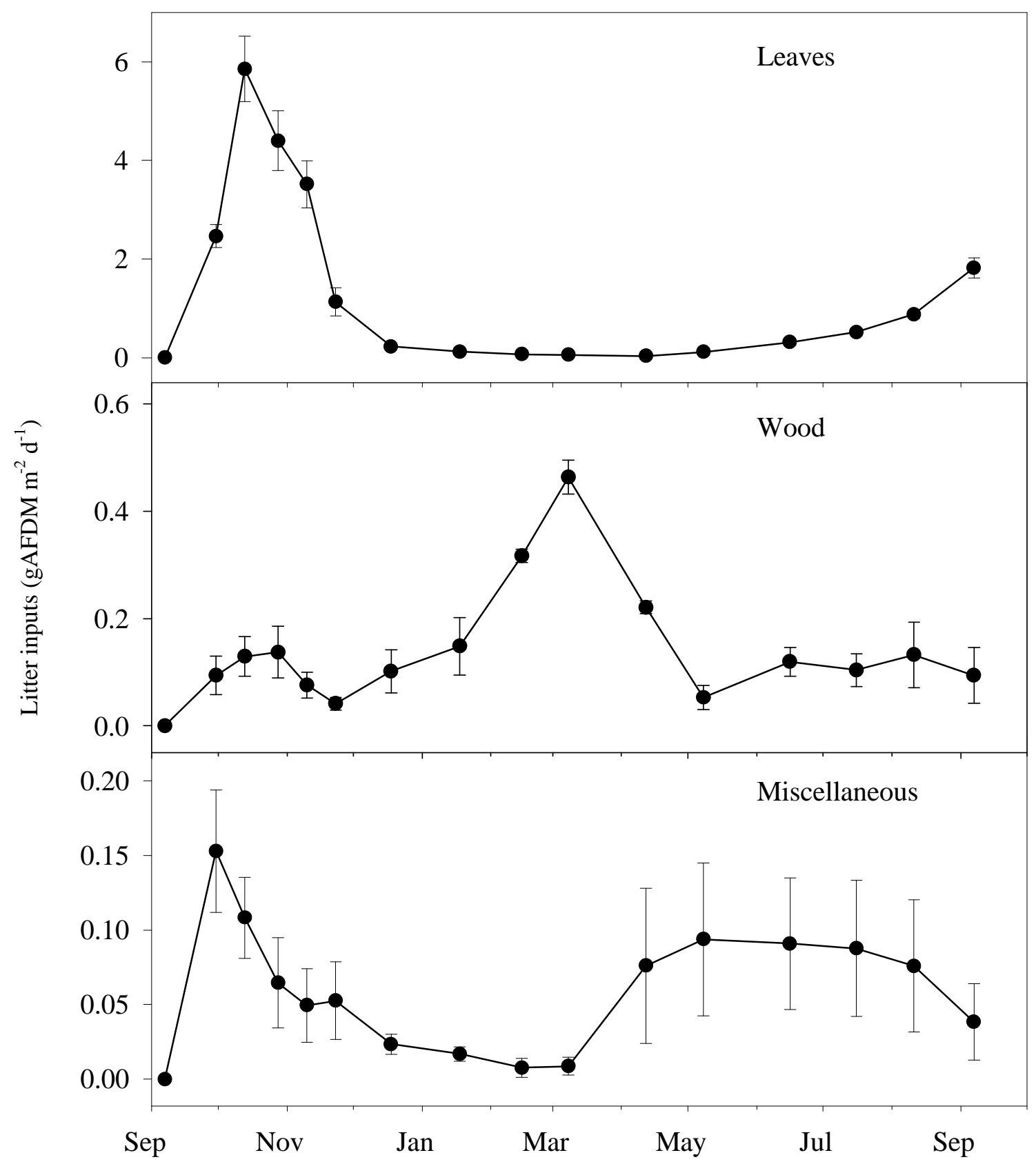

Figure 5: Daily litter inputs rates of leaves, wood, and miscellaneous material to the floodplain of the Little Tennessee River, NC from September 1997 to September 1998. Values are means of sites combined ( $\pm 1 \mathrm{SE}$ of sites). 
Table 3: Tree species composition of leaffall to the Little Tennessee River floodplain from Sep 1997 to Dec 1997. Species are ordered by weight in $\mathrm{gAFDM} / \mathrm{m}^{2}$. Values are site means and are presented for species totalling at least $2 \%$ of the total weight.

\begin{tabular}{|c|c|c|c|c|c|c|c|c|c|c|c|c|c|c|}
\hline \multirow[b]{2}{*}{ Tree Species } & \multicolumn{14}{|c|}{ Site } \\
\hline & U1 & $\mathbf{U} 2$ & $\mathbf{U 3}$ & $\mathbf{U} 4$ & $\mathbf{U 5}$ & $\mathbf{L 1}$ & $\mathbf{L 2}$ & $\mathbf{L 3}$ & L4 & $\mathbf{L 5}$ & L6 & L7 & Mean & $\%$ of Total \\
\hline Platanus occidentalis & 46 & 25 & 1 & 53 & 31 & 153 & 19 & 73 & 45 & 1 & 14 & 88 & 46 & 17 \\
\hline Carpinus caroliniana & 47 & 57 & 91 & 102 & 0 & 3 & 55 & 81 & 0 & 4 & 66 & 11 & 43 & 16 \\
\hline Juglans nigra & 26 & 43 & 8 & 5 & 72 & 0 & 2 & 7 & 205 & 0 & 0 & 41 & 34 & 12 \\
\hline Misc. leaves & 37 & 17 & 13 & 19 & 33 & 45 & 47 & 36 & 16 & 18 & 25 & 56 & 30 & 11 \\
\hline Acer rubrum & 3 & 0 & 1 & 89 & 8 & 0 & 61 & 88 & 0 & 2 & 98 & 1 & 29 & 11 \\
\hline Carya glabra & 0 & 0 & 0 & 0 & 8 & 0 & 61 & 0 & 0 & 142 & 0 & 0 & 18 & 6 \\
\hline Halesia caroliniana & 31 & 0 & 0 & 6 & 0 & 0 & 66 & 5 & 0 & 5 & 8 & 63 & 15 & 6 \\
\hline Liriodendron tulipfera & 2 & 0 & 1 & 25 & 0 & 0 & 62 & 0 & 0 & 0 & 46 & 0 & 11 & 4 \\
\hline Prunus serotina & 23 & 2 & 4 & 0 & 19 & 0 & 21 & 15 & 1 & 0 & 0 & 20 & 9 & 3 \\
\hline Quercus alba & 0 & 0 & 0 & 0 & 0 & 0 & 0 & 0 & 0 & 1 & 81 & 0 & 7 & 2 \\
\hline Nyssa sylvatica & 39 & 1 & 0 & 1 & 0 & 0 & 0 & 0 & 0 & 0 & 31 & 0 & 6 & 2 \\
\hline
\end{tabular}




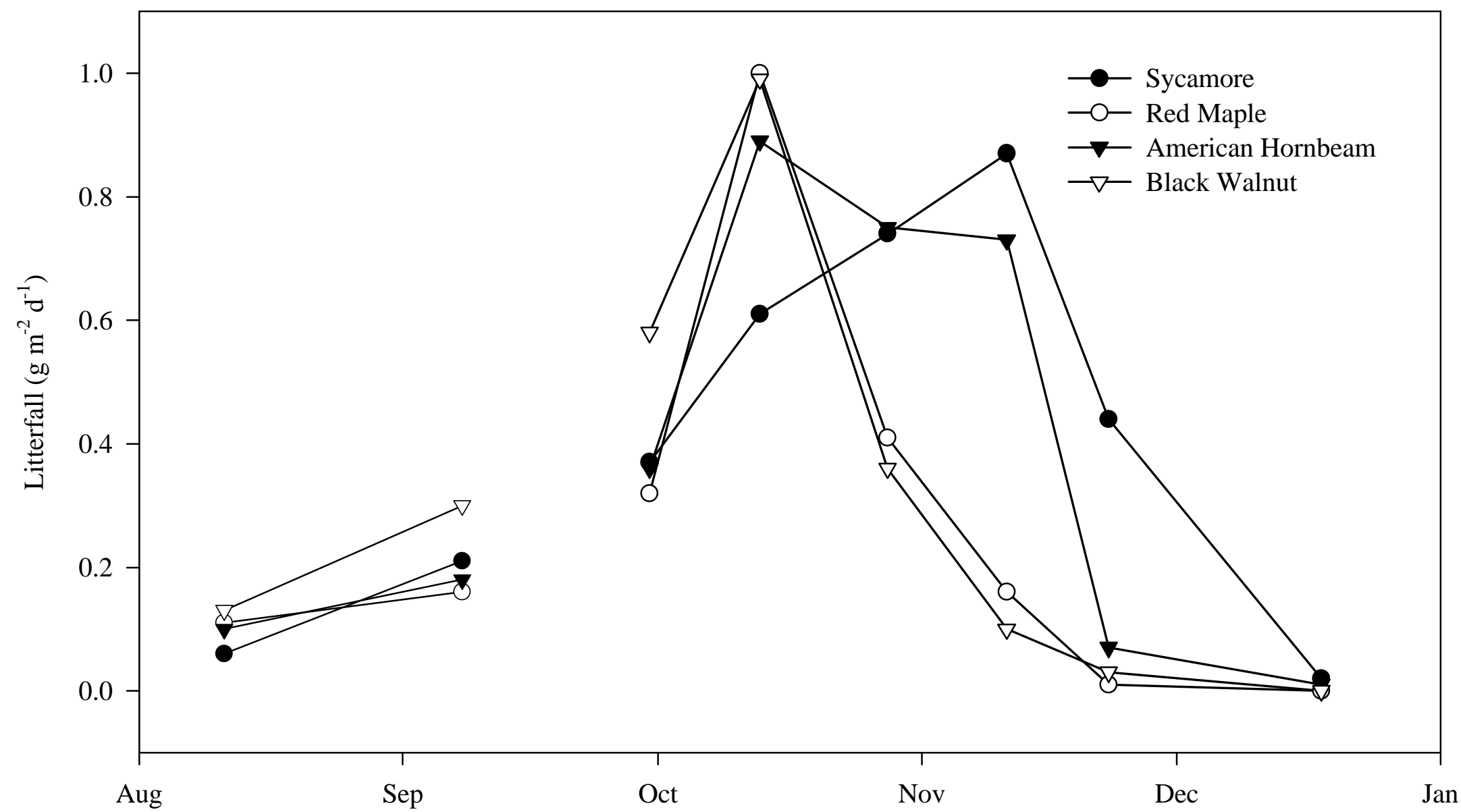

Figure 6: Autumn leaffall rates of four common floodplain species to the floodplain of the Little Tennessee River, NC. Daily rates are based on means for all sites. August and September data are from 1998, and the other data are from 1997. 
occurred in mid October, there were substantial leaf inputs in August and September. Peak leaf inputs of red maple occurred in early October followed by a sharp decline. Leaf inputs of American hornbeam were rather steady throughout the fall with maximum inputs occurring from October to early November. In contrast to other species, sycamore fell later in autumn with peak inputs occurring in late October and early November.

\section{Herbaceous Aboveground Net Primary Production}

Annual herbaceous aboveground net primary production (ANPP) was highly variable among sites as well as within each site (Table 4). Mean herbaceous ANPP was

$223 \mathrm{gAFDM} \mathrm{m}^{-2} \mathrm{y}^{-1}$ and ranged from $61 \mathrm{gAFDM} \mathrm{m}^{-2} \mathrm{y}^{-1}$ at site U4 to $439 \mathrm{gAFDM} \mathrm{m}^{-2} \mathrm{y}^{-1}$ at site L3. Sites were significantly different (one-way ANOVA, $p<0.05$ ). One site, L3, was specifically responsible for this difference and was significantly greater than sites U4, L2, and L6 (Tukey's test, $p<0.05$ ).

Herbaceous ANPP was regressed as a function and this regression was not significant (Figure 7A, $p>0.05, r^{2}=0.06$ ). However, the fit of the regression appeared to greatly affected by one outlier, site L3. When this outlier was removed, the regression was significant (Figure 7B, $p<0.05$ ), but was still not very predictive $\left(r^{2}=0.37\right)$. Nearly every site also had greater annual leaffall than herbaceous ANPP (Figure 7). One site, U3, had greater herbaceous ANPP than leaffall, and another site, U2, had similar annual herbaceous ANPP and leaffall.

\section{Leaf Breakdown}

Leaf breakdown varied among species (Figure 8). Sycamore had a significantly slower breakdown rate than the other three species $(p<0.05)$. Furthermore, red maple also had a significantly slower breakdown rate than black walnut $(p<0.05)$. In contrast, black walnut $\left(k=0.0100 \mathrm{~d}^{-1}\right)$ and American hornbeam $\left(k=0.0072 \mathrm{~d}^{-1}\right)$ had similar breakdown rates $(p>0.05)$, as did red maple and American hornbeam $(p>0.05)$. Three species, American hornbeam, black walnut, and red maple had similar \%AFDM remaining at the end of the experiment: red maple had 26\%, American hornbeam had $22 \%$, and black walnut had $19 \%$. In contrast, sycamore was slow throughout the duration 
Table 4: Annual herbaceous ANPP of sites on the floodplain of the Little Tennessee River, NC. Values are means with standard deviation given in parentheses. Sites with the same letter did not have significantly different herbaceous ANPP (ANOVA, Tukey's, p>0.05)

\begin{tabular}{lc}
\hline Site & $\begin{array}{c}\text { Herbaceous ANPP } \\
\left(\mathrm{gAFDM} \mathrm{m} \mathrm{y}^{-1}\right)\end{array}$ \\
\hline $\mathrm{U} 1^{\mathrm{ab}}$ & $226(181)$ \\
$\mathrm{U} 2^{\mathrm{ab}}$ & $248(191)$ \\
$\mathrm{U}^{\mathrm{ab}}$ & $289(189)$ \\
$\mathrm{U} 4^{\mathrm{a}}$ & $61(30)$ \\
$\mathrm{U} 5^{\mathrm{ab}}$ & $212(77)$ \\
$\mathrm{L}^{\mathrm{ab}}$ & $276(115)$ \\
$\mathrm{L}^{\mathrm{a}}$ & $105(86)$ \\
$\mathrm{L}^{\mathrm{b}}$ & $439(331)$ \\
$\mathrm{L}^{\mathrm{ab}}$ & $278(115)$ \\
$\mathrm{L}^{\mathrm{ab}}$ & $199(122)$ \\
$\mathrm{L}^{\mathrm{a}}$ & $77(37)$ \\
$\mathrm{L} 7^{\mathrm{ab}}$ & $267(170)$ \\
\hline Mean & $\mathbf{2 2 3}(\mathbf{1 0 5})$ \\
\hline
\end{tabular}




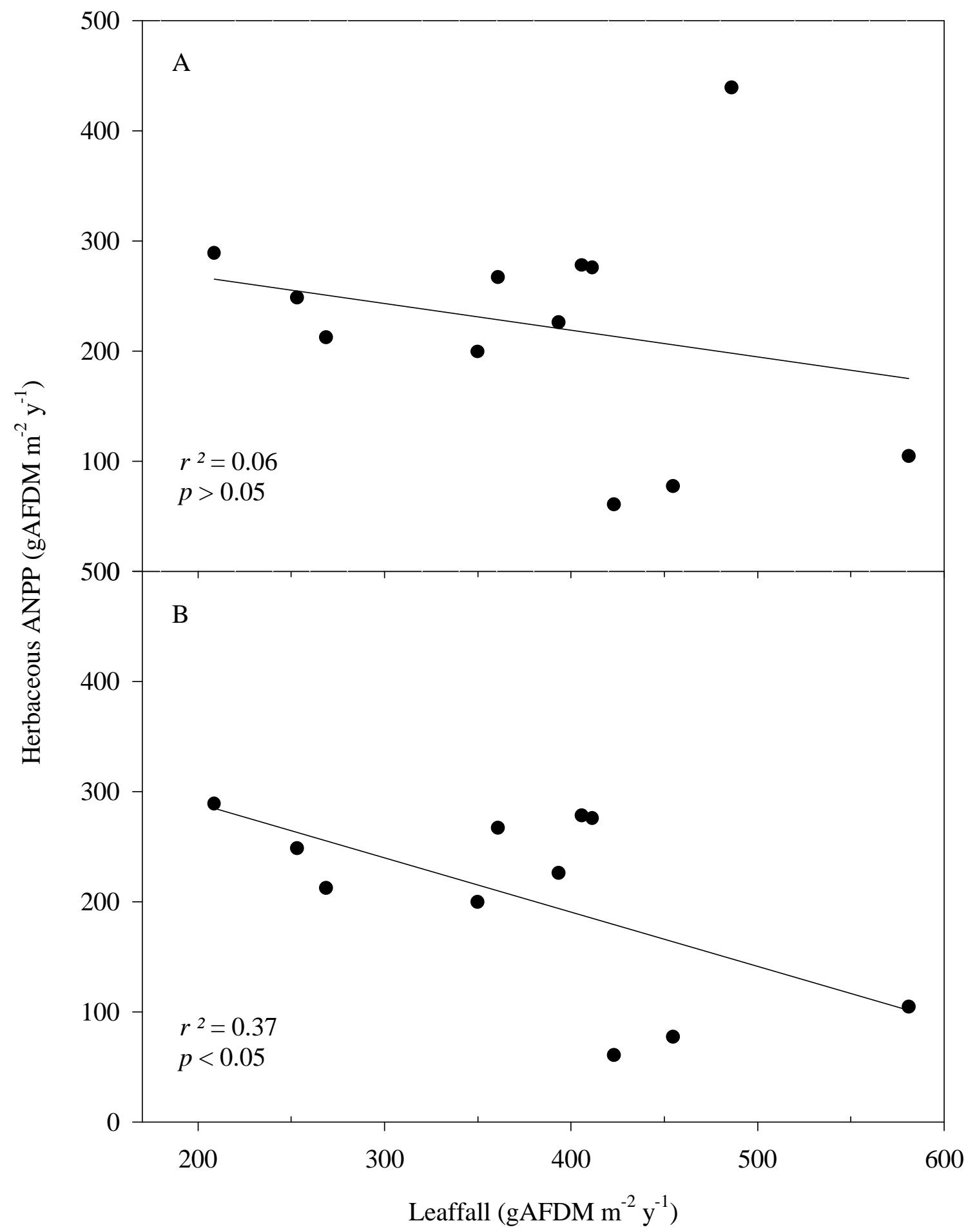

Figure 7: Herbaceous ANPP as a function of leaffall with (A) and without (B) site L3. Sites are represented by points. 


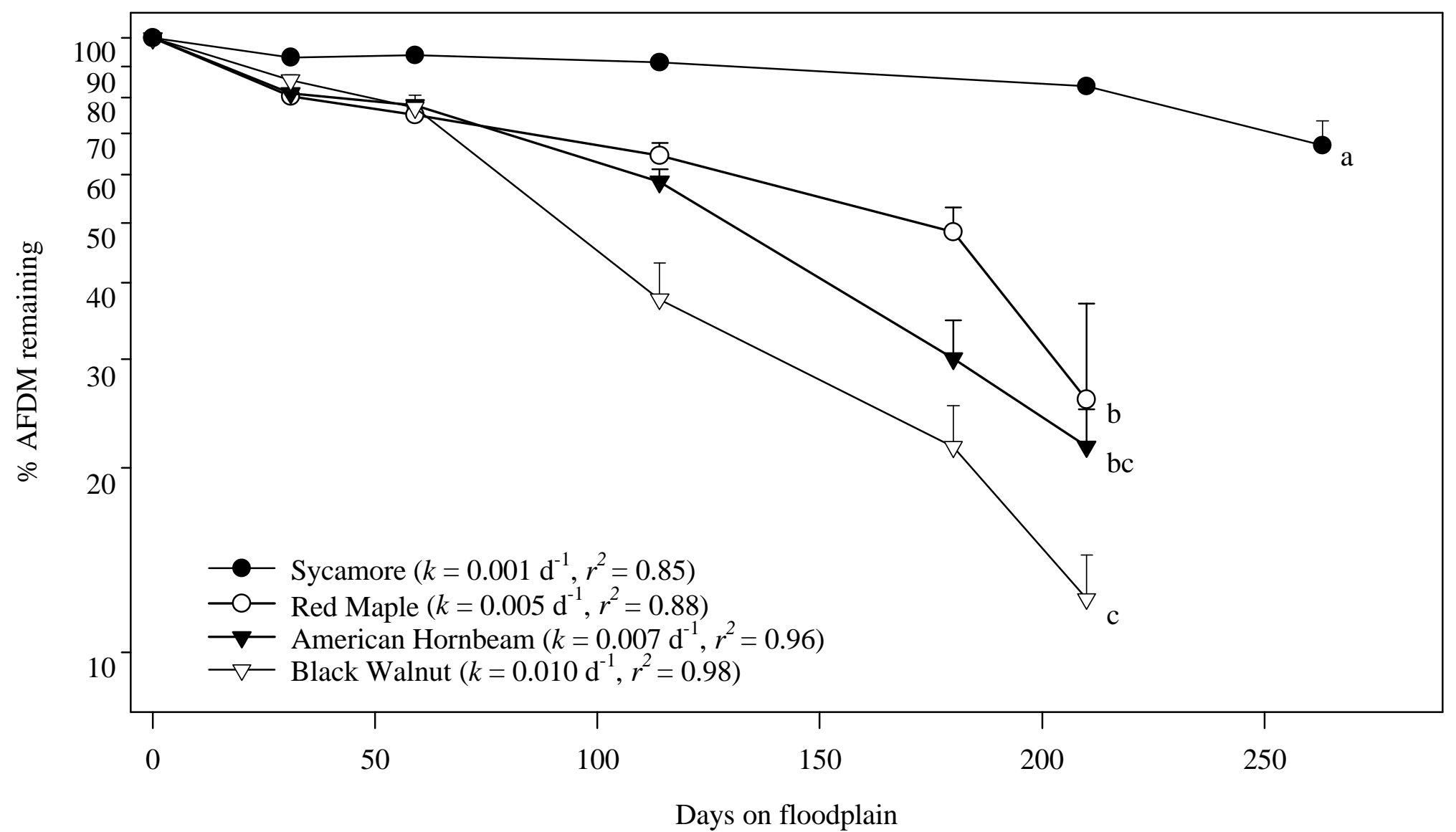

Figure 8: Leaf breakdown of the four common floodplain tree species as \% AFDM remaining (+1 SE) based on mean breakdown of all leaf packs. Species with the different letters are significantly different (dummy variable analysis, $p<0.05$ ). Values in parenthesis are mean species breakdown rate $(k)$ and coefficient of determination $\left(r^{2}\right)$. 
of the study. Over $65 \%$ of the original leaf mass was remaining nine months after initial placement.

The flood of January 1998 had different effects on the four species (Figure 9), although the flood generally appeared to increase the rate of leaf breakdown. Leaf packs of red maple and black walnut inundated by the flood had significantly faster breakdown rates than non-inundated leaf packs $(p<0.05)$. Sycamore and American hornbeam, however, were not significantly affected by flood inundation $(p>0.05)$.

\section{Floodplain Litter}

Floodplain litter (FPL) was highly variable within and among sites for leaves, herbaceous material, and wood for both pre- and post-flood measurements (Tables 5, 6, and 7). However, each litter component appeared to be affected differently by the flood of January 1998.

Before the flood (December 1997), total standing crop of leaves on the floodplain ranged from 165 to $243 \mathrm{gAFDM} / \mathrm{m}^{2}$ (Table 5). Mean leaf standing crop was 277 $\mathrm{gAFDM} / \mathrm{m}^{2}$ at the inundated sites, $232 \mathrm{gAFDM} / \mathrm{m}^{2}$ at the partially-inundated sites, and $294 \mathrm{gAFDM} / \mathrm{m}^{2}$ at the non-inundated sites. Adjustments to pre-flood leaves for leaffall and leaf breakdown to predict 31 January 1998 leaves (post-flood) changed the standing crop to varying degrees at different sites. At all sites, the adjustments resulted in a decrease in standing crop.

Without correcting the standing crop for debris piles, post-flood leaves (January 1998) ranged from 29 to $385 \mathrm{gAFDM} / \mathrm{m}^{2}$ on the floodplain (Table 5). The mean standing crop was $123 \mathrm{gAFDM} / \mathrm{m}^{2}$ at the inundated sites, $170 \mathrm{gAFDM} / \mathrm{m}^{2}$ at the partiallyinundated sites, and $237 \mathrm{gAFDM} / \mathrm{m}^{2}$ at the non-inundated sites. Debris pile adjustments to post-flood leaves varied at the sites where debris piles were measured (Table 5). The adjustments were sometimes substantial (e.g., site L7, 14 gAFDM/m²) or negligible (site $\mathrm{U} 1,0.30 \mathrm{gAFDM} / \mathrm{m}^{2}$ ). At one site (U4), the debris piles resulted in slight negative adjustment of mean post-flood leaves, suggesting that there were fewer leaves in the debris piles (i.e., more wood and herbaceous material) than on the floodplain as a whole. Following corrections for debris, mean leaf standing crop increased to $126 \mathrm{gAFDM} / \mathrm{m}^{2}$ at the inundated sites and $175 \mathrm{gAFDM} / \mathrm{m}^{2}$ at the partially-inundated sites. 


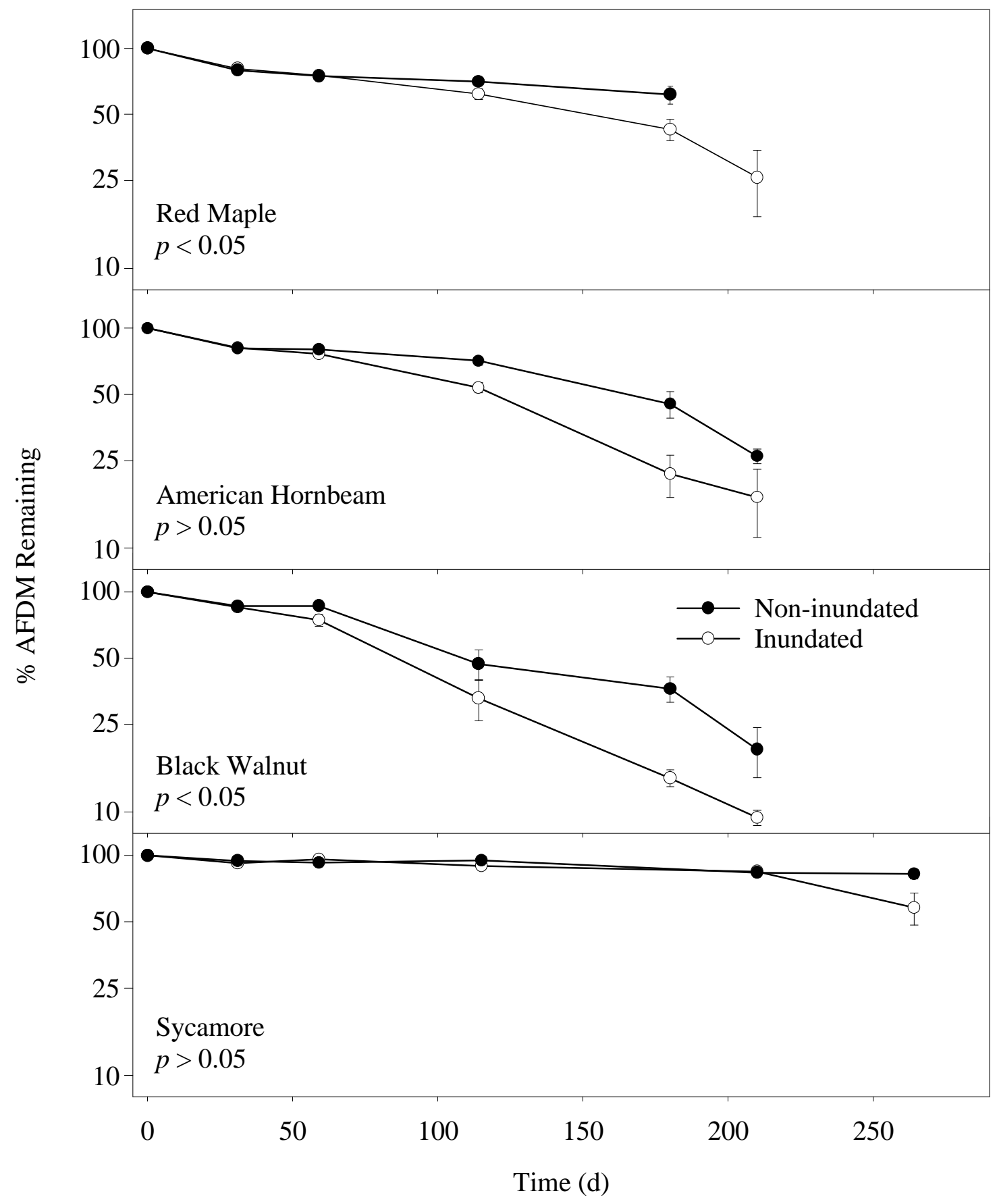

Figure 9: Leaf breakdown $( \pm 1 \mathrm{SE})$ of inundated and non-inundated leaf packs. Leaf packs for a given species were compared using a general linear model with a dummy variable. The flood occurred on day 21. 
Table 5: Pre-flood (18-19 Dec 97) and post-flood (30-31 Jan 98) leaf litter standing crop on the floodplain. Values are means in $\mathrm{gAFDM} / \mathrm{m}^{2}$ with standard deviation given in parentheses. Pre-flood leaves were used to predict 31 January 1998 leaves in the absence of a flood. Net change is the difference between the predicted standing crop and the measured post-flood standing crop with debris pile adjustments.

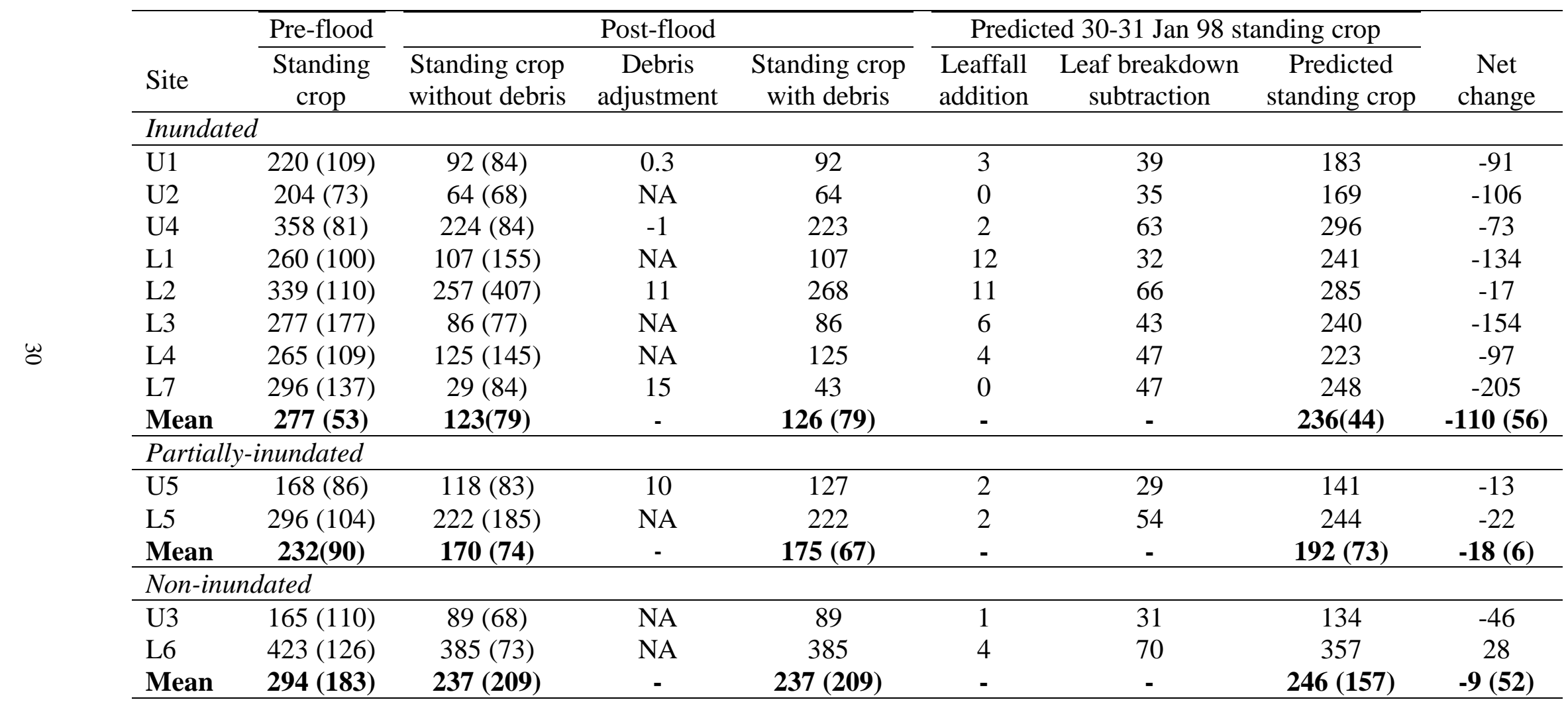


Table 6: Pre-flood (18-19 Dec 97) and post-flood (30-31 Jan 98) herbaceous standing crop on the floodplain. Values are means in $\mathrm{gAFDM} / \mathrm{m}^{2}$ with standard deviation given in parentheses.

\begin{tabular}{|c|c|c|c|c|}
\hline \multirow[b]{2}{*}{ Site } & \multirow{2}{*}{$\begin{array}{c}\text { Pre-flood } \\
\text { Standing crop }\end{array}$} & \multicolumn{3}{|c|}{ Post-flood } \\
\hline & & $\begin{array}{l}\text { Standing crop } \\
\text { without debris }\end{array}$ & $\begin{array}{c}\text { Debris } \\
\text { adjustment }\end{array}$ & $\begin{array}{l}\text { Standing crop } \\
\text { with debris }\end{array}$ \\
\hline \multicolumn{5}{|c|}{ Inundated } \\
\hline U1 & $137(218)$ & $76(132)$ & 36 & 112 \\
\hline $\mathrm{U} 2$ & $53(48)$ & $31(57)$ & NA & 31 \\
\hline U4 & $32(21)$ & $39(16)$ & 72 & 110 \\
\hline L1 & $93(89)$ & $35(85)$ & NA & 35 \\
\hline $\mathrm{L} 2$ & $35(33)$ & $108(134)$ & 4 & 111 \\
\hline L3 & $74(40)$ & $20(16)$ & NA & 20 \\
\hline $\mathrm{L} 4$ & $142(111)$ & $184(332)$ & NA & 184 \\
\hline L7 & $85(71)$ & $34(41)$ & 7 & 41 \\
\hline Mean & $82(42)$ & $66(56)$ & - & $81(60)$ \\
\hline \multicolumn{5}{|c|}{ Partially-inundated } \\
\hline U5 & $81(41)$ & $114(138)$ & 13 & 127 \\
\hline L5 & $61(49)$ & $71(41)$ & NA & 71 \\
\hline Mean & $71(14)$ & $92(30)$ & - & $99(40)$ \\
\hline \multicolumn{5}{|c|}{ Non-inundated } \\
\hline $\mathrm{U3}$ & $30(33)$ & $28(25)$ & NA & 28 \\
\hline L6 & $33(22)$ & $26(10)$ & NA & 26 \\
\hline Mean & $32(2)$ & 27 (1) & - & $27(1)$ \\
\hline
\end{tabular}


Table 7: Pre-flood (18-19 Dec 97) and post-flood (30-31 Jan 98) wood standing crop on the floodplain. Values are means in $\mathrm{gAFDM} / \mathrm{m}^{2}$ with standard deviation given in parentheses.

\begin{tabular}{|c|c|c|c|c|}
\hline \multirow[b]{2}{*}{ Site } & \multirow{2}{*}{$\begin{array}{c}\text { Pre-flood } \\
\text { Standing crop }\end{array}$} & \multicolumn{3}{|c|}{ Post-flood } \\
\hline & & $\begin{array}{l}\text { Standing crop } \\
\text { without debris }\end{array}$ & $\begin{array}{c}\text { Debris } \\
\text { adjustment }\end{array}$ & $\begin{array}{l}\text { Standing crop } \\
\text { with debris }\end{array}$ \\
\hline \multicolumn{5}{|c|}{ Inundated } \\
\hline U1 & $271(262)$ & $132(177)$ & 16 & 148 \\
\hline $\mathrm{U} 2$ & $294(642)$ & $119(282)$ & NA & 119 \\
\hline U4 & $111(215)$ & 65 (109) & 42 & 107 \\
\hline L1 & $141(139)$ & 89 (117) & NA & 89 \\
\hline $\mathrm{L} 2$ & $246(314)$ & $264(290)$ & 35 & 299 \\
\hline L3 & $113(169)$ & $47(97)$ & NA & 47 \\
\hline $\mathrm{L} 4$ & $140(161)$ & $65(128)$ & NA & 65 \\
\hline L7 & $148(221)$ & $54(114)$ & 19 & 73 \\
\hline Mean & $183(74)$ & $105(71)$ & - & $118(80)$ \\
\hline \multicolumn{5}{|c|}{ Partially-inundated } \\
\hline U5 & $49(102)$ & $24(38)$ & -1 & 23 \\
\hline L5 & $38(47)$ & $28(30)$ & NA & 28 \\
\hline Mean & $44(8)$ & $26(3)$ & - & $25(3)$ \\
\hline \multicolumn{5}{|c|}{ Non-inundated } \\
\hline $\mathrm{U3}$ & $24(92)$ & $11(17)$ & NA & 11 \\
\hline L6 & $161(218)$ & 161(129) & NA & 161 \\
\hline Mean & $92(97)$ & 86 (107) & - & 86 (107) \\
\hline
\end{tabular}


The mean net change in standing crop between the predicted post-flood standing crop and the measured post-flood standing crop was $-110 \mathrm{gAFDM} / \mathrm{m}^{2}$ at the inundated sites, ranging from -17 to $-205 \mathrm{gAFDM} / \mathrm{m}^{2}$. In contrast, the mean change in standing crop was only $-18 \mathrm{gAFDM} / \mathrm{m}^{2}$ at the partially-inundated sites and $-9 \mathrm{gAFDM} / \mathrm{m}^{2}$ at the non-inundated sites. The post-flood standing crops were significantly smaller than the predicted standing crop for the inundated class (Figure 10,p<0.05, paired t-test), suggesting a flood effect. In fact, all inundated sites showed a loss of leaves. However, neither the partially-inundated class nor the non-inundated class showed a significant difference between the predicted and actual post-flood standing crops when analyzed individually or combined $(p>0.05)$.

Pre-flood herbaceous standing crop ranged from 30 to $142 \mathrm{gAFDM} / \mathrm{m}^{2}$ on the floodplain (Table 6). Mean herbaceous material was $82 \mathrm{gAFDM} / \mathrm{m}^{2}$ at the inundated sites, $71 \mathrm{gAFDM} / \mathrm{m}^{2}$ at the partially-inundated sites, and $32 \mathrm{gAFDM} / \mathrm{m}^{2}$ at the noninundated sites. Before correcting the standing crop for debris, post-flood herbaceous material ranged from 26 to $184 \mathrm{gAFDM} / \mathrm{m}^{2}$. For sites that were inundated, mean herbaceous material was $66 \mathrm{gAFDM} / \mathrm{m}^{2}$, and was $92 \mathrm{gAFDM} / \mathrm{m}^{2}$ and $27 \mathrm{gAFDM} / \mathrm{m}^{2}$ at the partially-inundated and non-inundated sites, respectively. Correction for debris piles had a profound effect at one site (U4), the post-flood standing crop was nearly tripled. Debris corrections at other sites ranged from 4 to $36 \mathrm{gAFDM} / \mathrm{m}^{2}$. After debris pile adjustment, mean herbaceous material increased to $81 \mathrm{gAFDM} / \mathrm{m}^{2}$ at the inundated sites and $99 \mathrm{gAFDM} / \mathrm{m}^{2}$ at the partially-inundated sites. The pre- and corrected post-flood herbaceous standing crops were not significantly different for any of the inundation classes (Figure 10,p>0.05). Some sites showed an increase in standing crop while some sites showed a decrease.

Before the flood, floodplain wood standing crop ranged from 38 to 294 $\mathrm{gAFDM} / \mathrm{m}^{2}$. Mean wood was $183 \mathrm{gAFDM} / \mathrm{m}^{2}$ at the inundated sites, $44 \mathrm{gAFDM} / \mathrm{m}^{2}$ at the partially-inundated sites, and $86 \mathrm{gAFDM} / \mathrm{m}^{2}$ at the non-inundated sites. After the flood, wood standing crop ranged from 24 to $264 \mathrm{gAFDM} / \mathrm{m}^{2}$ without correcting for debris piles. The mean standing crop was $105 \mathrm{gAFDM} / \mathrm{m}^{2}$ for the inundated sites and 26 $\mathrm{gAFDM} / \mathrm{m}^{2}$ and $86 \mathrm{gAFDM} / \mathrm{m}^{2}$ for the partially-inundated sites and non-inundated sites, respectively. Debris corrections resulted in an increase in standing crop at all inundated 


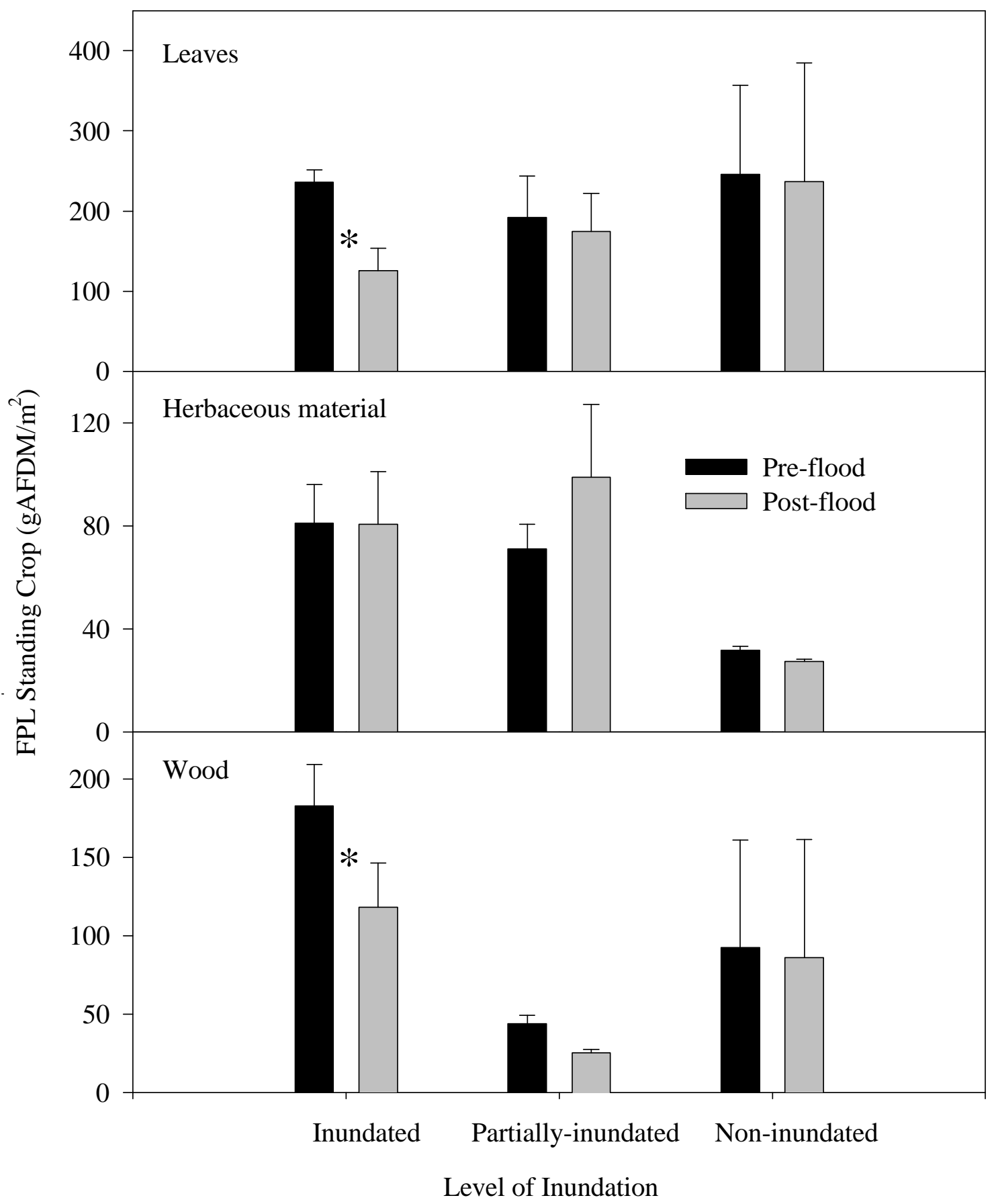

Figure 10: Comparison of pre- and post-flood FPL $(+1 \mathrm{SE})$ among inundated $(n=8)$, partially-inundated $(n=2)$, and non-inundated sites $(n=2)$ for leaves, herbaceous material, and wood. The asterisk indicates a significant difference between pre- and post-flood FPL (paired t-test, $p<0.05$ ). 
sites where debris piles were collected, ranging from 16 to $42 \mathrm{gAFDM} / \mathrm{m}^{2}$. For all inundated sites, the post-flood wood standing crop was significantly lower than the preflood standing crop (Figure 10, $p<0.05$ ). However, neither the partially-inundated nor the non-inundated classes showed a significant difference between pre- and post-flood wood individually or combined $(p>0.05)$.

\section{Floodplain Litter Computer Model}

FPL standing crop (leaves only) of inundated, partially inundated, and noninundated sites fluctuated temporally (Figure 11). The annual maximum FPL standing crop was in mid-November during autumn leaffall and the minimum occurred in mid to late summer. Sites U2, L5, and L7 were omitted from the analysis because leaffall was not measured for the entire study year.

When using leaf breakdown rates based on non-inundated leaf packs, the steady state values obtained from the computer model were generally larger than actual pre- or post-flood leaves measured in the field (Table 8). At 5 of 6 inundated sites, model predicted values were larger than actual values (pre-flood). The difference of model

leaves to actual leaves ranged from $-7 \mathrm{gAFDM} / \mathrm{m}^{2}$ to $+256 \mathrm{gAFDM} / \mathrm{m}^{2}(-3 \%$ to $+92 \%)$. When inundated sites were grouped together, the model overestimated both the actual pre- and post-flood leaf standing crop (Figure 11). The model similarly overestimated actual leaves at site U5, a partially-inundated site (Table 8, Figure 11). The difference between the model leaves and actual leaves was $33 \mathrm{gAFDM} / \mathrm{m}^{2}(19 \%)$. The model showed mixed results in predicting leaves of the non-inundated sites. Model leaves were $78 \mathrm{gAFDM} / \mathrm{m}^{2}$ (18\%) higher than actual leaves for site L6, but $17 \mathrm{gAFDM} / \mathrm{m}^{2}(10 \%)$ lower for site U3. When these two sites were combined, however, the model predicted leaves was very close in predicting both the actual pre- and post-flood leaves standing crop (Figure 11).

\section{Leaf Inputs to the River}

Direct leaffall and flood leaf inputs to the river are summarized in Table 9. Assuming that $10 \mathrm{~m}$ of forested area on both sides of the river had been inundated during 


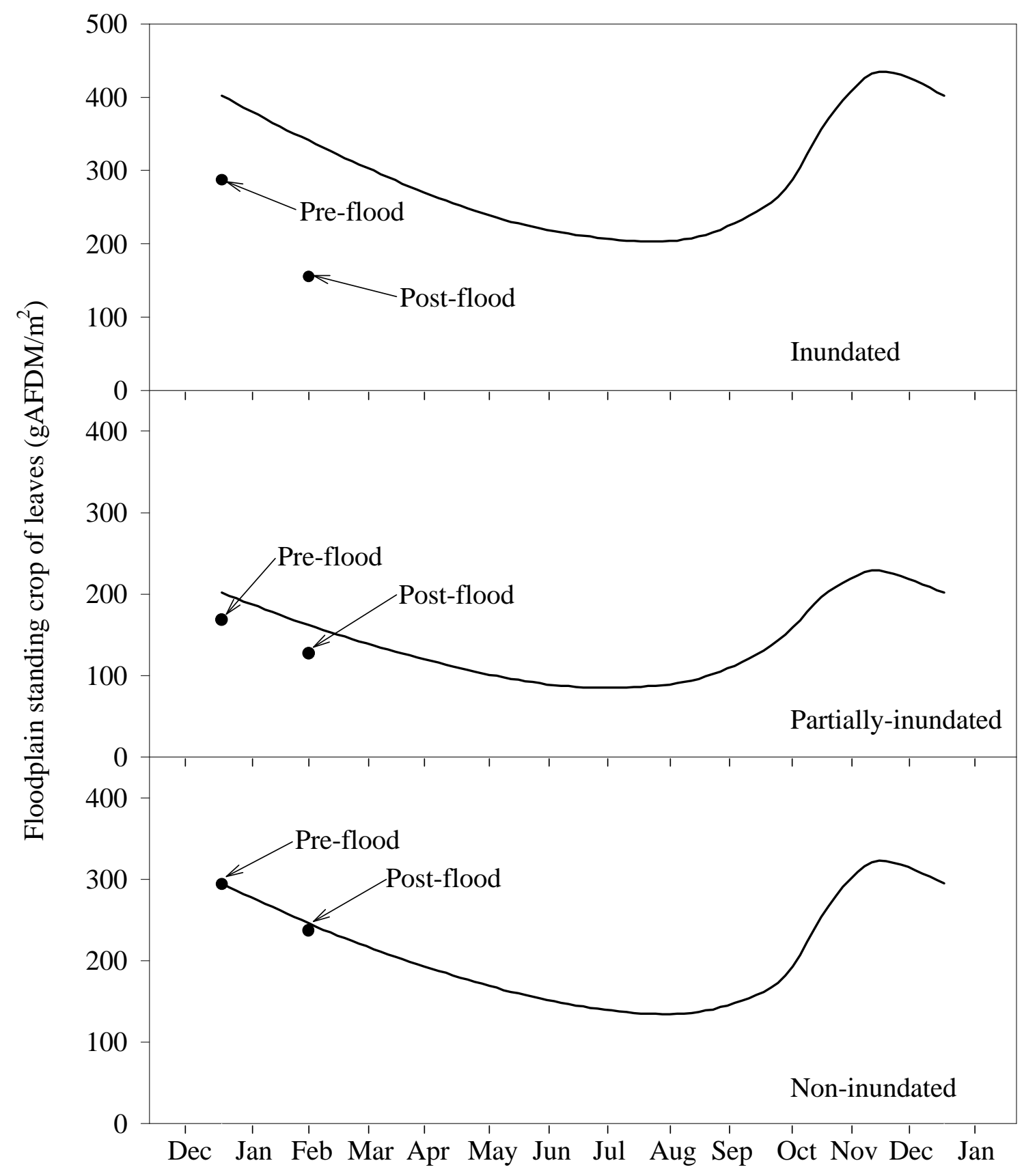

Time

Figure 11: Annual fluctuation of model predicted floodplain standing crop of leaves in steady state. Non-inundated breakdown rates $(k)$ were used to obtain steady state values. Mean measured standing crop of leaves (pre-flood and post-flood) of each inundation level are indicated by arrows. 
Table 8: Site standing crop comparison of actual floodplain leaf standing crop and steady state leaf standing crop derived from computer model in $\mathrm{gAFDM} / \mathrm{m}^{2}$ on $18 \mathrm{Dec} 97$. Sites U2, L5, and L7 were omitted because leaffall was not measured for the entire study year.

\begin{tabular}{lcccc}
\hline Site & Actual & Model* & $\begin{array}{c}\text { Difference } \\
\text { (Model - Actual) }\end{array}$ & \% Difference \\
\hline Inundated & & & & \\
\hline U1 & 220 & 336 & 716 & 53 \\
U4 & 358 & 428 & 231 & 20 \\
L1 & 260 & 491 & 158 & 88 \\
L2 & 339 & 497 & 256 & 47 \\
L3 & 277 & 533 & -7 & 92 \\
L4 & 265 & 258 & & -3 \\
\hline Partially-inundated & & & 33 & 19 \\
\hline U5 & 168 & 201 & & -10 \\
\hline Non-Inundated & & & -17 & 18 \\
\hline U3 & 165 & 148 & 78 & \\
L6 & 423 & 501 & & \\
\hline
\end{tabular}

* Steady state standing crop was determined from computer model using non-inundated breakdown rates $(k)$ for each site. 
Table 9: Flood leaf inputs and direct leaffall to the Little Tennessee River, NC. River leaffall was calculated assuming all littertraps were placed $2 \mathrm{~m}$ from the river banks. Flood transport of leaves from the floodplain was calculated assuming that 10 $\mathrm{m}$ of forested area on both sides of the river had been inundated.

\begin{tabular}{|c|c|c|c|c|c|}
\hline & $\begin{array}{l}\text { Direct leaffall to } \\
\text { floodplain } \\
\left(\mathrm{gAFDM} / \mathrm{m}^{2}\right)\end{array}$ & $\begin{array}{c}\text { Direct leaffall to } \\
\text { river } \\
\left(\mathrm{gAFDM} / \mathrm{m}^{2}\right)\end{array}$ & $\begin{array}{c}\text { Flood export from } \\
\text { floodplain } \\
\text { (gAFDM/m) }\end{array}$ & $\begin{array}{l}\text { Flood inputs to } \\
\text { river } \\
\left(\mathrm{gAFDM} / \mathrm{m}^{2}\right)\end{array}$ & $\begin{array}{l}\text { Total inputs to } \\
\text { river } \\
\left(\mathrm{gAFDM} / \mathrm{m}^{2}\right)\end{array}$ \\
\hline \multicolumn{6}{|l|}{ Inundated } \\
\hline U1 & 392 & 105 & 1840 & 105 & 165 \\
\hline $\mathrm{U} 2$ & 253 & 96 & 2120 & 96 & 192 \\
\hline $\mathrm{U} 4$ & 422 & 141 & 1460 & 141 & 199 \\
\hline L1 & 411 & 90 & 2680 & 90 & 161 \\
\hline L2 & 581 & 61 & 340 & 61 & 65 \\
\hline L3 & 485 & 92 & 3080 & 92 & 162 \\
\hline L4 & 406 & 77 & 1940 & 77 & 121 \\
\hline L7 & 361 & 39 & 4100 & 39 & 91 \\
\hline Mean & 414 & 87 & 2195 & 87 & 144 \\
\hline \multicolumn{6}{|c|}{ Partially-inundated } \\
\hline U5 & 269 & 107 & - & 107 & 107 \\
\hline L5 & 350 & 53 & - & 53 & 53 \\
\hline Mean & 310 & 80 & - & 80 & 80 \\
\hline \multicolumn{6}{|c|}{ Non-inundated } \\
\hline $\mathrm{U} 3$ & 209 & 70 & - & 70 & 70 \\
\hline L6 & 455 & 42 & - & 42 & 42 \\
\hline Mean & 332 & 56 & - & 56 & 56 \\
\hline All Sites & 383 & 81 & 1463 & 81 & 119 \\
\hline
\end{tabular}


the January 1998 flood, flood export from the floodplain ranged from 340 to 4100 $\mathrm{gAFDM} / \mathrm{m}$ with a mean of $2195 \mathrm{gAFDM} / \mathrm{m}$ for the inundated sites. However, flood transport was considered to be zero for the partially-inundated and non-inundated sites because these sites did not have significantly different pre- and post-flood leaves as shown earlier. When these sites were incorporated, mean flood transport from the floodplain decreased to $1463 \mathrm{gAFDM} / \mathrm{m}$.

Annual direct leaffall to the river was $81 \mathrm{gAFDM} \mathrm{m}^{-2} \mathrm{y}^{-1}$ for all sites, ranging from 39 to $141 \mathrm{gAFDM} \mathrm{m}^{-2} \mathrm{y}^{-1}$, and was generally higher than flood leaf inputs. Two sites (U2 and L7) had the same or greater annual flood inputs than direct leaffall. For the inundated sites, mean annual flood inputs constituted $40 \%$ of total allochthonous leaf inputs to the river. However, when partially-inundated and non-inundated sites were included, flood inputs composed $32 \%$ of total allochthonous leaf inputs.

\section{Tree Assemblages}

A correspondence analysis (reciprocal averaging) was used to determine differences in tree assemblages among sites. Sites were plotted in species space based on the total DBH of each tree species within a site (Figure 12). DBH was used instead of basal area to minimize the effects of rare species. An eigenanalysis showed that the three axes created by the reciprocal averaging ordination explained approximately an equal amount of the variation between sites (Axis 1=38\%, Axis $2=32 \%$, Axis $3=30 \%$ ).

Cross correlation of species with each axis showed which species were important in determining the spatial distribution of sites in species space (Table 10). One tree species, black walnut, was positively correlated with axis 1 and several species were significant negative correlates with this axis 1 ( $p<0.05)$. In general, species negatively correlated with axis 1 are later successional species and black walnut, positively correlated with this axis, is an early successional species. Although axes 2 and 3 explained a large percentage of the variance, neither of these two axes revealed any general differences in tree assemblages. Black walnut was positively correlated with axis $2(p<0.05)$. However, axis 2 was mainly driven by the presence a single strong negative correlate, sycamore $(p<0.05)$. The other species negatively correlated with this axis, 


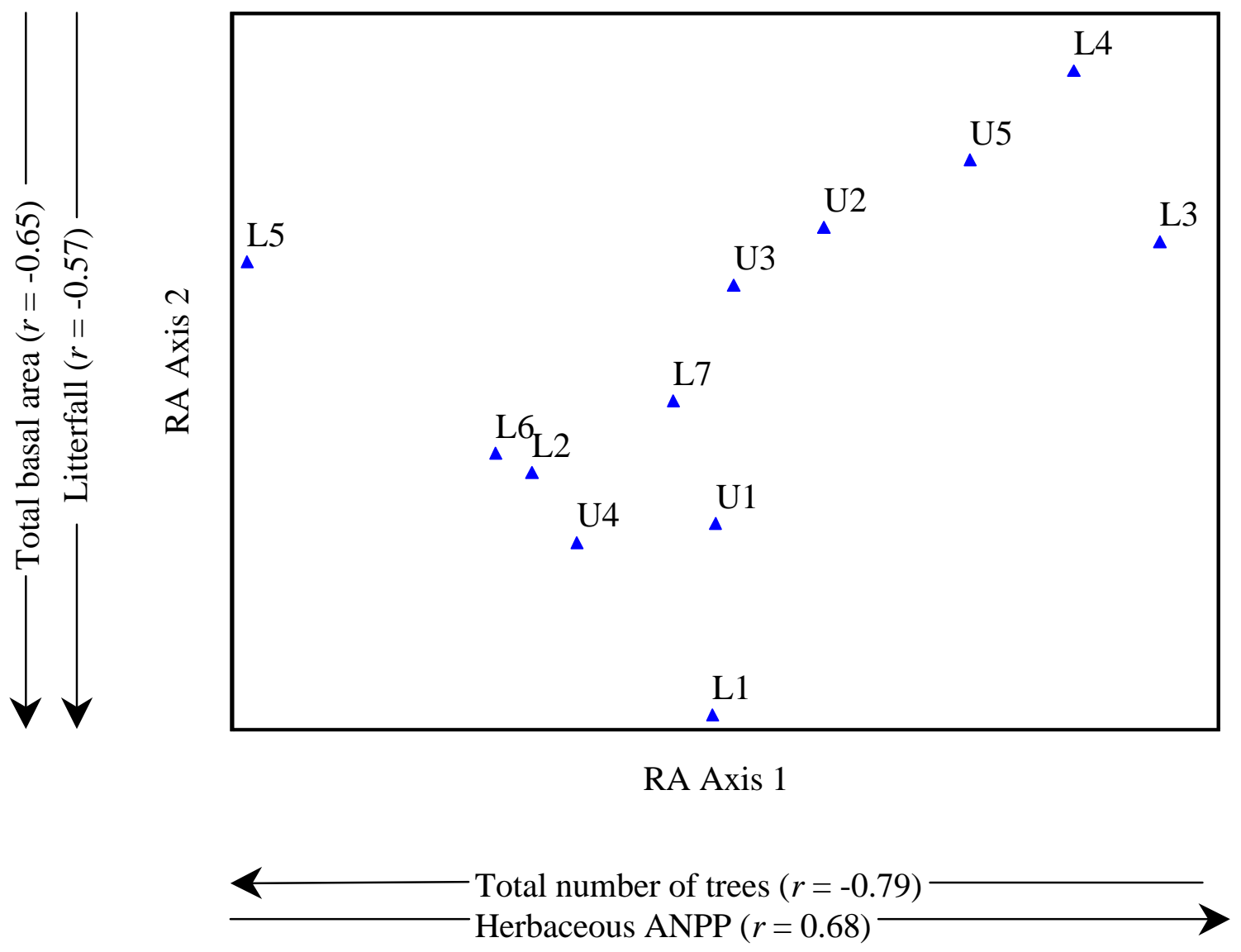

Figure 12: Correspondence analysis (reciprocal averaging) of sites in species space. Values for the data matrix were based on total DBH of each species at a given site. Biological variables significantly correlated with each axis are listed under the corresponding axis (Pearson correlation, $p<0.05$ ) 
Table 10: Pearson correlations $(r, p<0.05)$ of tree species with corresponding reciprocal averaging ordination axes. Species are presented in order of $r$.

\begin{tabular}{lc}
\hline & RA Axis 1 \\
\hline Species & $\mathrm{r}$ \\
\hline Carpinus caroliniana & -0.88 \\
Pinus virginiana & -0.66 \\
Quercus rubra & -0.66 \\
Kalmia latifolia & -0.65 \\
Carya glabra & -0.64 \\
Acer rubrum & -0.61 \\
Calycanthus floridus & -0.59 \\
Juglans nigra & 0.59 \\
\hline
\end{tabular}

RA Axis 2

\begin{tabular}{lc}
\hline Platanus occidentalis & -0.82 \\
Robinia pseudoacacia & -0.73 \\
Salix nigra & -0.60 \\
Juglans nigra & 0.56 \\
\hline
\end{tabular}

RA Axis 3

Celtis laevigata

Juniperus virginiana

Lindera benzoin

Symplocos tinctoria
0.95

0.95

0.95

0.95 
black locust (Robinia pseudoacacia) and black willow (Salix nigra), were very dominant at site L1, which also had a highest DBH of sycamore. Axis 3 was determined by several rare species: sugarberry (Celtis laevigata), eastern redcedar (Juniperas virginiana), spicebush (Lindera benzoin), and sweatleaf (Symplocus tinctoria). These species were positively correlated with this axis but only found at site L3.

Several biological variables were related to the tree assemblage of the Little Tennessee River floodplain (Figure 12). Total number of trees per site was negatively correlated with axis 1 and herbaceous NPP was positively correlated with axis 1 ( $p<$ 0.05). In addition, total basal area of all trees per site and annual litterfall were negatively correlated with axis $2(p<0.05)$. No biological variables, however, were significantly correlated with axis 3 .

Total tree basal area and abundance of each site in the first and second $10 \times 100 \mathrm{~m}$ plots were ordered by axis 1 (Figure 13). Four sites (U3, U5, L3, L4), located on the right side of axis 1, completely lacked trees in the second $10 \times 100 \mathrm{~m}$ plot, indicating that these sites consisted of a thin riparian strip of woody vegetation. These sites also had low overall number of trees and basal area relative to sites on the left side of this axis. These sites were also more evenly distributed in both basal area and number of trees between the first and second $10 \times 100$ m plots. A few sites had large relative differences between basal area and number of trees. For example, the basal area of site U1 was $15.3 \mathrm{~m}^{2}$, the largest value any site, which was due to the presence of a few large trees, particularly sycamore. Conversely, site L5 had a large number of trees relative to basal area, which was mainly due to a ubiquitous small shrub, sweet-shrub (Calycanthus floridus).

There were 38 tree species surveyed on the floodplain of the Little Tennessee River (Appendix B). When site importance values (IV) of trees were ordered along ordination axis 1, many species were locally important at a few sites. A suite of spices were important primarily at sites on the left side of axis 1 (e.g. pignut hickory and yellow-poplar), while black walnut was more important at sites on the left side. (Table 11). Black walnut also had a relatively low ratio of floodplain basal area to density (Table 12). Some species were locally important at only one site that either lay on the left (e.g., sweetshrub), middle (e.g., Asimina triloba), or right (e.g., spicebush) of axis 1 (Table 11). However, American hornbeam and sycamore were important at many sites 


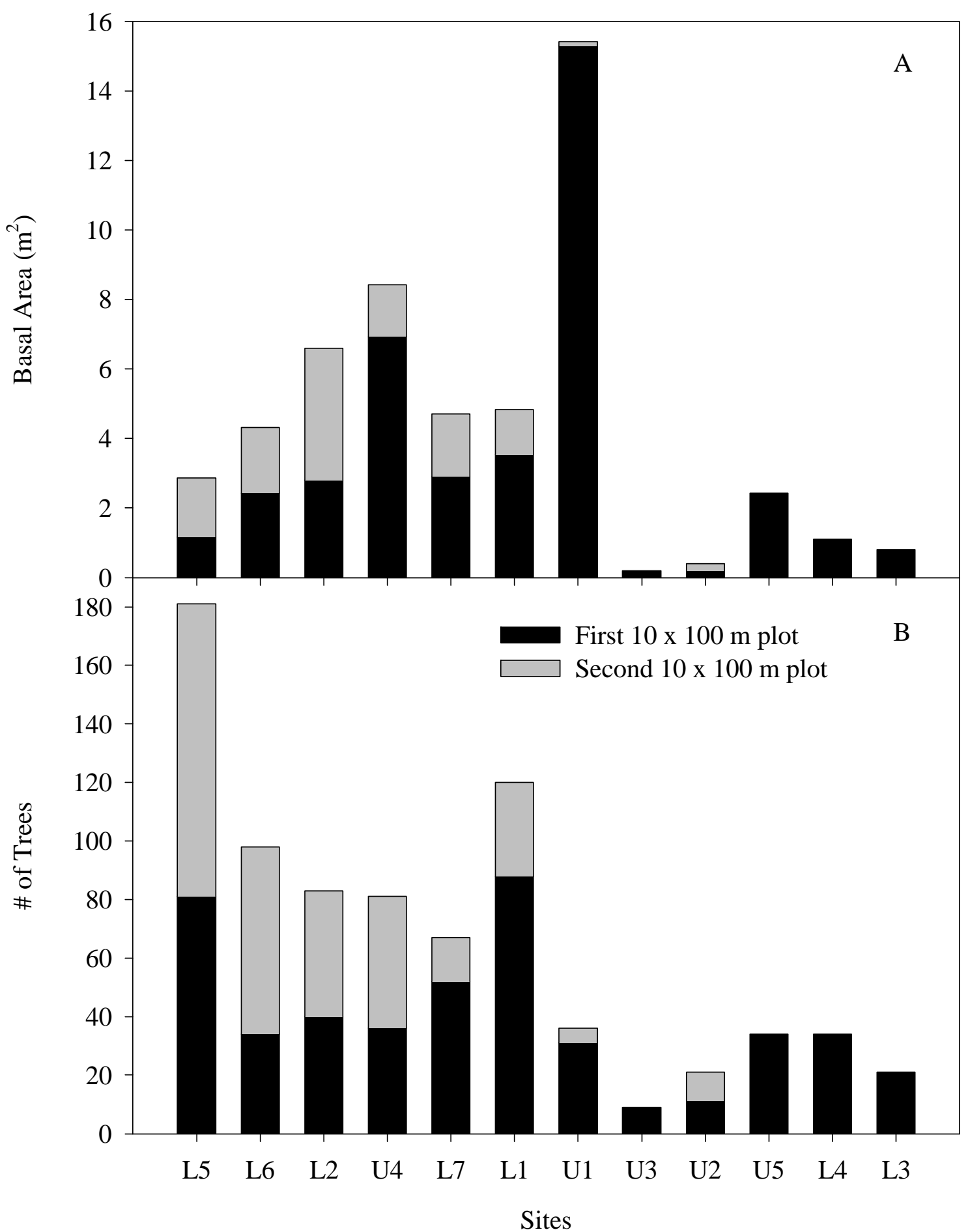

Figure 13: Tree composition based on total basal area (A) and total number of trees (B) per site. The stacked bars represent tree composition in the first and second $10 \times 100 \mathrm{~m}$ plots. Sites are ordered by RA ordination axis 1. 
Table 11: Importance values (IV = relative basal area + relative density) for trees (stems $\geq 2 \mathrm{~cm} \mathrm{DBH)} \mathrm{of} 12$ sites on the Little Tennessee River floodplain. Species are ordered by RA ordination axis 1. Values are presented for species having IV $\geq 2$ at all sites combined or IV $\geq 15$ at any one site. Importance values are based on a possible score of 200 .

\begin{tabular}{|c|c|c|c|c|c|c|c|c|c|c|c|c|}
\hline \multirow[b]{2}{*}{ Species } & \multicolumn{12}{|c|}{ Sites } \\
\hline & L5 & L6 & L2 & U4 & L7 & L1 & U1 & U3 & U2 & U5 & L4 & L3 \\
\hline Carya glabra & 58.4 & 4.6 & 5.2 & - & - & - & - & - & - & - & - & - \\
\hline Calycanthus floridus & 37.7 & - & - & - & - & - & - & - & - & - & - & - \\
\hline Quercus alba & - & 15.2 & - & - & - & - & - & - & - & - & - & - \\
\hline Liriodendron tulipfera & - & 49.4 & 45.1 & 7.5 & - & - & 13.6 & - & - & 7.1 & - & - \\
\hline Diospyros virginiana & 0.9 & 7.5 & 2.6 & 4.4 & - & - & - & - & - & - & - & - \\
\hline Acer rubrum & 12.4 & 22.0 & 39.7 & 25.9 & 67.5 & - & 10.1 & - & - & - & - & - \\
\hline Carpinus caroliniana & 57.0 & 45.4 & 35.8 & 56.6 & 2.4 & 17.9 & 15.7 & 82.2 & 69.8 & - & - & 6.1 \\
\hline Halesia caroliniana & 4.1 & 25.5 & 15.8 & 2.0 & 32.1 & - & 9.0 & - & - & 14.0 & - & 24.8 \\
\hline Asimina triloba & - & - & - & 34.3 & - & - & - & - & - & - & - & - \\
\hline Salix nigra & - & - & - & - & 2.3 & 33.2 & - & - & - & - & - & - \\
\hline Robinia pseudoacacia & - & 2.7 & 16.3 & - & - & 29.2 & 12.5 & - & - & - & - & - \\
\hline Cornus sp. & 3.5 & 5.4 & - & 5.1 & 14.6 & 22.6 & - & - & - & - & 14.5 & - \\
\hline Platanus occidentalis & - & 3.4 & 9.6 & 56.7 & 11.9 & 87.8 & 85.5 & - & - & - & - & 36.1 \\
\hline Prunus serotina & - & - & 8.6 & 3.2 & 9.6 & 5.7 & 25.5 & 31.0 & 40.6 & 52.2 & 4.6 & - \\
\hline Juglans nigra & - & - & 2.6 & - & 17.1 & 3.5 & 20.8 & 75.4 & 89.6 & 112.7 & 180.9 & 24.4 \\
\hline Lindera benzoin & - & - & - & - & - & - & - & - & - & - & - & 66.4 \\
\hline
\end{tabular}


Table 12: Basal area, density, and importance values (relative basal area + relative density) of tree species (stems $\geq 2 \mathrm{~cm} \mathrm{DBH}$ ) on the floodplain of the Little Tennessee River floodplain. Values are presented for species having IV $\geq 2$.

\begin{tabular}{lccc}
\hline Tree Species & $\begin{array}{c}\text { Basal Area } \\
\left(\mathbf{m}^{\mathbf{2}} / \mathbf{h a}\right)\end{array}$ & $\begin{array}{c}\text { Density } \\
\text { (\# of trees/ha) }\end{array}$ & IV \\
\hline Platanus occidentalis & 8.22 & 21 & 43.7 \\
Carpinus caroliniana & 2.11 & 57 & 29.1 \\
Carya glabra & 2.11 & 23 & 17.1 \\
Acer rubrum & 2.52 & 16 & 16.7 \\
Juglans nigra & 1.17 & 30 & 15.6 \\
Liriodendron tulipfera & 2.21 & 11 & 13.6 \\
Halesia caroliniana & 0.74 & 17 & 9.2 \\
Cornus sp. & 0.15 & 21 & 8.0 \\
Prunus serotina & 0.55 & 15 & 7.6 \\
Calycanthus floridus & 0.13 & 20 & 7.5 \\
Robinia pseudoacacia & 0.78 & 5 & 5.3 \\
Salix nigra & 0.41 & 7 & 4.3 \\
Asimina triloba & 0.04 & 11 & 4.0 \\
Diospyros virginiana & 0.06 & 5 & 2.0 \\
\hline
\end{tabular}


regardless of axis 1 . On the floodplain as a whole, American hornbeam was rather ubiquitous and had the highest density of all species (Table 12). In contrast, sycamore had the greatest basal area. These two species constituted $36 \%$ of total tree importance on the floodplain. 


\section{Discussion}

\section{Floodplain Particulate Organic Matter Dynamics}

POM inputs to the Little Tennessee River floodplain consisted of litterfall and herbaceous ANPP. Overall, floodplain litterfall was $448 \mathrm{gAFDM} \mathrm{m}^{-2} \mathrm{y}^{-1}$, which was within the range of 240 to $810 \mathrm{gAFDM} \mathrm{m}^{-2} \mathrm{y}^{-1}$ for warm temperate angiosperm forests (Bray and Gorham 1964) but lower than values reported for other floodplain forests (Table 13). Leaf and wood inputs were also smaller than most floodplain forests. In contrast, litterfall composition was similar to values reported for other floodplain forests. Leaffall constituted nearly $90 \%$ of all litter inputs to the floodplain, which exceeded the expected mean of $70 \%$ for angiosperm forests (Bray and Gorham 1964). Shure and Gottschalk (1985) suggested that this high ratio of leaves to non-leaves is a result of large leaf area on floodplains.

Floodplain littertraps used in this study may have underestimated litterfall for a contiguous floodplain forest. Traps were placed approximately $2 \mathrm{~m}$ from the banks of the river and received minimal litter inputs from the stream side of the traps. Assuming maximum canopy cover occurred at $10 \mathrm{~m}$ from the banks of the river, maximum floodplain litterfall estimated from equation 2 was $747 \mathrm{gAFDM} \mathrm{m}^{-2} \mathrm{y}^{-1}$, ranging from 389 to $1042 \mathrm{gAFDM} \mathrm{m}^{-2} \mathrm{y}^{-1}$. Annual leaffall was $672 \mathrm{gAFDM} \mathrm{m}^{-2} \mathrm{y}^{-1}$, ranging from 376 to $1002 \mathrm{gAFDM} \mathrm{m}^{-2} \mathrm{y}^{-1}$. These values were similar to what has been observed in other floodplain forests (Table 13). However, these floodplain maxima were calculated based on the assumption that all sites have greater than $20 \mathrm{~m}$ of woody vegetation from the banks of the river. Many sites have less than $20 \mathrm{~m}$ of woody riparian vegetation and thus maximum floodplain litterfall may occur at or near the banks of the river.

Other studies measuring litterfall or herbaceous ANPP on the floodplain have been conducted mostly in forested floodplains. The floodplain of the Little Tennessee River, however, is impacted by anthropogenic land use, primarily agriculture. Although 90\% of the Little Tennessee River watershed was forested in 1990 (Wear and Bolstad 1998), only $57 \%$ of the riparian area within $30 \mathrm{~m}$ of the river was forested (McTammany, personal communication using GIS overlays from SAMAB land cover data of the Little Tennessee River catchment). The non-forested riparian areas have little or no woody 
Table 13: Litter inputs to river/floodplain ecosystems of the eastern United States.

\begin{tabular}{|c|c|c|c|c|}
\hline $\begin{array}{l}\text { River/floodplain } \\
\text { ecosystem }\end{array}$ & $\begin{array}{l}\text { Litterfall } \\
\left(\mathrm{g} \mathrm{m}^{-2} \mathrm{y}^{-1}\right)\end{array}$ & $\begin{array}{c}\text { Leaves }^{\mathrm{a}} \\
\left(\mathrm{g} \mathrm{m}^{-2} \mathrm{y}^{-1}\right)\end{array}$ & $\begin{array}{c}\text { Wood } \\
\left(\mathrm{g} \mathrm{m}^{-2} \mathrm{y}^{-1}\right)\end{array}$ & References \\
\hline $\begin{array}{l}\text { Little Tennessee River, } \\
\text { North Carolina }\end{array}$ & $\begin{array}{l}448 \\
747^{b}\end{array}$ & $\begin{array}{l}403 \\
672^{b}\end{array}$ & $\begin{array}{l}45 \\
75^{b}\end{array}$ & This study \\
\hline $\begin{array}{l}\text { Sangamon River, } \\
\text { Illinois }\end{array}$ & 575 & 506 & 69 & Bell et al. (1978) \\
\hline $\begin{array}{l}\text { Sangamon River, } \\
\text { Illinois }\end{array}$ & 797 & 491 & 306 & $\begin{array}{l}\text { Peterson and Rolfe } \\
\text { (1982) }\end{array}$ \\
\hline $\begin{array}{l}\text { Buzzards Branch, } \\
\text { Virginia }\end{array}$ & 527 & 489 & 38 & Smock (1990) \\
\hline $\begin{array}{l}\text { Colliers Creek, } \\
\text { Virginia }\end{array}$ & 963 & 538 & 425 & Smock (1990) \\
\hline $\begin{array}{l}\text { Creeping Swamp, } \\
\text { North Carolina }\end{array}$ & 605 & 472 & 178 & Mulholland (1981) \\
\hline $\begin{array}{l}\text { Lower Three Runs Creek, } \\
\text { South Carolina }\end{array}$ & 635 & 524 & 111 & $\begin{array}{l}\text { Shure and Gottschalk } \\
\text { (1985) }\end{array}$ \\
\hline $\begin{array}{l}\text { Ogeechee River, } \\
\text { Georgia }\end{array}$ & 901 & 839 & 62 & Cuffney (1988) \\
\hline $\begin{array}{l}\text { Prairie Creek, } \\
\text { Florida }\end{array}$ & 597 & 536 & 61 & Brown (1981) \\
\hline
\end{tabular}

includes leaves and reproductive material.

bcalculated floodplain maximum values 
riparian vegetation. Many of my sites were located in these non-forested areas, which resulted in lower annual litterfall. DeLong and Brusven (1994) observed that litterfall was lower in areas with riparian vegetation typical of agriculture than in more forested riparian areas of Lapwai Creek in Idaho. When I excluded sites consisting of $<10 \mathrm{~m}$ strip of woody riparian vegetation, floodplain litterfall increased to $525 \mathrm{gAFDM} \mathrm{m}^{-2} \mathrm{y}^{-1}$, with leaf and wood inputs of $461 \mathrm{gAFDM} \mathrm{m}^{-2} \mathrm{y}^{-1}$ and $65 \mathrm{gAFDM} \mathrm{m}^{-2} \mathrm{y}^{-1}$, respectively. However, many of my sites (e.g. U1, L3, L4) consisting of woody riparian strips $<10 \mathrm{~m}$ had similar or higher annual litterfall than sites with more forested riparian areas.

Annual litterfall is typically higher in floodplain forests than adjacent upland forests (Webster et al. 1995). Floodplains have a low water table which results in greater soil moisture. In addition, flood waters may provide subsidies of nutrients and water. This may enhance primary productivity of woody floodplain vegetation producing greater litterfall totals (Conner and Day 1976, Brinson et al. 1980, Gomez and Day 1982). The floodplain of the Little Tennessee River, however, is generally not inundated as frequently or as long as other floodplains where litterfall studies have been conducted. Since 1945, floods have occurred about once every 2 years and have lasted 1-2 days. Thus, greater litterfall totals associated with frequently inundated floodplain forests may not be realized on the Little Tennessee River floodplain. Other studies, however, have suggested that frequent flooding may stress root systems of woody riparian vegetation, which may decrease primary production (Mitsch and Rust 1984, Megonigal et al. 1997). Thus adjacent upland forests may have similar or greater litterfall totals.

Herbaceous ANPP was $223 \mathrm{gAFDM} \mathrm{m}{ }^{-2} \mathrm{y}^{-1}$, which was higher than values reported for a Illinois floodplain forest (Peterson and Rolfe 1982). Only leaf inputs were a greater annual input to the floodplain than herbaceous ANPP. At some sites, however, herbaceous ANPP was similar or greater than annual leaffall. I expected that herbaceous ANPP and leaf inputs should be inversely related, assuming that leaffall is a good measure of the degree of canopy cover. Other studies have shown that the degree of canopy cover and herbaceous production are inversely related (Scifres et al. 1983, Schacht et al. 1988, McPherson et al. 1990). In my study, however, there was a weak relationship between leaffall and herbaceous ANPP, suggesting that either greater canopy cover does not limit herbaceous ANPP or leaffall was not a good measure of the degree 
of canopy cover. As mentioned earlier, many of my sites consisted of a thin strip of woody riparian vegetation. Thus, these sites had high light penetration from either side of the riparian strip, which may have resulted in high herbaceous ANPP.

When leaf breakdown rates of the species in my study were compared, sycamore had a much slower breakdown rate than the other three species: red maple, American hornbeam, and black walnut. Breakdown rates of different species have been shown to differ widely (Webster and Benfield 1986). Sycamore typically has been shown to have a slow breakdown rate (Benfield 1977, Hauer 1986), which may be due to presence of inhibitory chemicals (e.g. cutins), low nitrogen concentrations, or high fiber content (Webster and Benfield 1986).

The leaf breakdown rates of all species, regardless of inundation level, were much faster than values reported for other temperate terrestrial ecosystems (Aerts 1997). However, leaf breakdown rates of all species except black walnut were at the high end of the range of other floodplain forests $\left(0.0004-0.009 \mathrm{~d}^{-1}\right)$ in the eastern United States (Table 14), although none of these studies measured leaf breakdown of the same species used in my study. Floodplains are mesic ecosystems that receive nutrient subsidies via transport from flood waters. Hence, breakdown rates are typically greater than adjacent upland areas (Peterson and Rolfe 1982, Shure et al. 1986) unless floodplain soils become anoxic, which may impede breakdown (Cuffney and Wallace 1987).

Leaf breakdown rates of all species were also similar to values reported for stream ecosystems, except sycamore, which was slightly slower than streams (Webster and Benfield 1986). This is contrary other studies which showed that leaf litter processing is slower in floodplains than in streams (Merritt and Lawson 1979, Webster and Benfield 1986, Cuffney and Wallace 1987, Gurtz and Tate 1988).

\section{Flood Effects on Floodplain POM Dynamics}

Areas inundated by the flood January 1998 had significantly faster leaf breakdown rates of red maple and black walnut than non-inundated areas. These findings support the results of others who have observed that floodplains regularly inundated by floods have faster leaf breakdown rates than non-flooded areas (Peterson and Rolf 1982, Shure et al. 1986, Molles et al. 1995). Furthermore, Gurtz and Tate (1985) found that 
Table 14: Leaf breakdown coefficients $(k)$ of species in river/floodplain ecosystems of the eastern United States.

\begin{tabular}{|c|c|c|c|}
\hline $\begin{array}{l}\text { River/floodplain } \\
\text { ecosystem }\end{array}$ & Species & $k\left(\mathrm{~d}^{-1}\right)$ & References \\
\hline $\begin{array}{l}\text { Little Tennessee River, } \\
\text { North Carolina }\end{array}$ & $\begin{array}{c}\text { Acer rubrum } \\
\text { Carpinus caroliniana } \\
\text { Juglans nigra } \\
\text { Platanus occidentalis }\end{array}$ & $\begin{array}{l}0.005 \\
0.007 \\
0.010 \\
0.001\end{array}$ & This study \\
\hline $\begin{array}{l}\text { Sangamon River, } \\
\text { Illinois }\end{array}$ & Mixed species & 0.007 & $\begin{array}{l}\text { Peterson and Rolfe } \\
\text { (1982) }\end{array}$ \\
\hline $\begin{array}{l}\text { Tar River, } \\
\text { North Carolina }\end{array}$ & Nyssa aquatica & 0.005 & Brinson (1977) \\
\hline $\begin{array}{l}\text { Lower Three Runs, } \\
\text { South Carolina }\end{array}$ & Mixed species & $0.003-0.005$ & Shure et al. (1986) \\
\hline $\begin{array}{l}\text { Lower Three Runs, } \\
\text { South Carolina }\end{array}$ & $\begin{array}{c}\text { Liquidambar styraciflua } \\
\text { Quercus nigra } \\
\text { Mixed species }\end{array}$ & $\begin{array}{l}0.001-0.002 \\
0.0006-0.0009 \\
0.0004-0.001\end{array}$ & $\begin{array}{l}\text { McArthur et al. } \\
\text { (1994) }\end{array}$ \\
\hline $\begin{array}{l}\text { Ogeechee River, } \\
\text { Georgia }\end{array}$ & $\begin{array}{c}\text { Liquidambar styraciflua } \\
\text { Quercus nigra }\end{array}$ & $\begin{array}{l}0.002-0.009 \\
0.001-0.003\end{array}$ & $\begin{array}{l}\text { Cuffney and } \\
\text { Wallace (1987) }\end{array}$ \\
\hline
\end{tabular}


breakdown rates were directly related to flood frequency and duration, especially for fast decomposing species. Slower decomposing species were not significantly affected by flooding. This explains why sycamore, a slow decomposing species, may have not been affected by the flood in my study.

Breakdown rates of red maple and black walnut could have been affected by the flood in several different ways. First, there may have been mechanical breakdown by the hydrologic power of the flood. This, however, is unlikely because there was not an abrupt decrease in \%AFDM remaining immediately following the flood. In fact, inundated and non-inundated leaf packs collected in January 1998 had nearly the same $\%$ AFDM remaining. Second, the flood may have transported nutrients to the floodplain from the river. Floodplains have been observed to act as sinks of nutrients (Mulholland 1981, Brown and Peterson 1983, Shure and Gottschalk 1985) and greater soil nutrient concentrations may increase leaf breakdown rates. Finally, I observed that the flood covered leaf packs with a layer of sediment from the river. This layer of sediment kept the leaf packs moist, whereas non-inundated leaf packs were often dry, such that the inundated packs were never water limited. Chaveut (1988), however, found that burial of leaves by sediments may slow breakdown and observed faster breakdown rates in drier soils.

The flood also caused a lateral transport of leaves and wood from the floodplain to the river via entrainment. This suggests that the floodplain is a source of POM for the river, which agrees with findings of other studies (Mulholland 1981, Cuffney 1988, Grubaugh and Anderson 1989, Tockner et al. 1999). Jones and Smock (1991), however, found that there was a net transport of wood and to a lesser extent leaves from the active channel of Colliers Creek to the floodplain, although Smock (1990) noted that coarse particulate organic matter (CPOM) is often broken down into smaller particles in this ecosystem before transport to the channel. Similarly, others observed that CPOM is often broken down in the floodplain during periods of inundation and is transported to the river as FPOM or DOM (Mulholland 1981, Grubaugh and Anderson 1989, Junk et al. 1989). These studies, however, have been conducted in large river systems or coastal plain streams where floodplain development is extensive and flood duration is long. The floodplain of Creeping Swamp Creek, for example, is typically inundated 5 mo annually 
(Mulholland 1981). In contrast, the flood in this study was a short pulse. Thus, POM was probably not broken down in the floodplain during flood inundation and transported to the river. Rather, the mechanism of flood removal was due to direct flood transport of large leaf and wood particles to the river via entrainment.

In contrast to flood transport of wood and leaves, there was no significant exchange of herbaceous material between the floodplain and river. Sites were variable in the amount of herbaceous material before and after the flood, but the floodplain was generally retentive of herbaceous material. In January, most herbaceous material was still firmly rooted in the ground, especially the grasses, such that herbaceous material was not easily entrained by the flood. In addition, herbaceous material was more likely to be retained in debris piles than either wood or leaves. Herbaceous material constituted about $44 \%$ of debris piles.

Across the entire floodplain, the loss of leaves observed in this study was negligible simply because the entire floodplain was not inundated. Furthermore, in areas inundated by the flood, flood export of leaves from the floodplain was $110 \mathrm{gAFDM} / \mathrm{m}^{-2}$ which represented a $47 \%$ removal of leaf standing crop at the time of the flood, but only $26 \%$ of annual leaf inputs. Although the export of litter may not be important annually, this suggests that the floodplain is an important storage area of leaves for the river, which release large amounts a leaves when floods occur. Other studies, in contrast, showed that floodplains are very retentive of POM (Smock 1990, Jones and Smock 1991, Cuffney 1988), although the floodplain may be a net exporter of POM.

Floods may be important in that they cause a long-term reduction of floodplain leaf standing crop. When floodplain leaf dynamics were modeled, leaf standing crop of the inundated sites was consistently overestimated. The pre-flood standing crop measured on 18 Dec 97 and predicted by the model were $287 \mathrm{gAFDM} / \mathrm{m}^{2}$ and 402 $\mathrm{gAFDM} / \mathrm{m}^{2}$, respectively. In contrast, the model predictions were relatively close to measured values for non-inundated and partially-inundated classes. For inundated sites, the overestimation of pre-flood leaves may indicate the effects of past floods on leaf standing crop. Leaf standing crop never reaches zero at anytime during the year so there is a holdover of leaves from the previous year. This may result in a stratification of leaf litter from the previous and current year. This is particularly true for sites that are 
dominated by slow decaying species, such as sycamore, which have turnover rates greater than $1 \mathrm{y}$.

The model was modified to incorporate the effects of floods on leaf standing crop. Floods were assumed to occur annually on 8 Jan and remove $50 \%$ of leaf standing crop. A new steady state was established and the simulated pre-flood standing crop decreased from $402 \mathrm{gAFDM} / \mathrm{m}^{2}$ in the absence of a flooding to $353 \mathrm{gAFDM} / \mathrm{m}^{2}$ in the new model. Additionally, when leaf breakdown rates of inundated packs were incorporated into the model, pre-flood leaf standing crop decreased to $325 \mathrm{gAFDM} / \mathrm{m}^{2}$. However, the Little Tennessee River floods about every other year, and the model was further modified accordingly. Given that the river did not flood in 1997, the simulated pre-flood leaf standing crop was predicted to be $386 \mathrm{gAFDM} / \mathrm{m}^{2}$, which was only slightly lower than predictions of the original model $\left(402 \mathrm{gAFDM} / \mathrm{m}^{2}\right)$. This suggests that there might not be a legacy of past floods in that they may have little effect on the store of leaves on the floodplain. Moreover, the model suggests that either leaf breakdown rates used in the model are too slow or that measured pre-flood standing crop was underestimated. Given that leaf breakdown rates measured in my study are at the high end of the range of other floodplain forests, leaf standing crop of the inundated sites was probably underestimated. This may have been a result of the uneven distribution of litter in areas that are frequently inundated.

\section{Leaf Inputs to the River}

Direct allochthonous leaffall to the river was $81 \mathrm{gAFDM} \mathrm{m}^{-2} \mathrm{y}^{-1}$ for the sixth and seventh order sections combined. When separated, the sixth order section received 104 gAFDM m ${ }^{-2} \mathrm{y}^{-1}$ and the wider seventh order section received $65 \mathrm{gAFDM} \mathrm{m}^{-2} \mathrm{y}^{-1}$. This was much lower than the average for eastern stream in deciduous forests which range from 202 to $538 \mathrm{gAFDM} \mathrm{m}^{-2} \mathrm{y}^{-1}$ (Webster et al. 1995). These streams, however, are mostly first and second order streams. For example, allochthonous inputs to streams at Coweeta Hydrologic Laboratory, which are in Little Tennessee River drainage, ranged from 460 to $600 \mathrm{gAFDM} \mathrm{m}^{-2} \mathrm{y}^{-1}$ (Benfield et al. 1998). Vannote et al. (1980) predicted that the amount of direct allochthonous inputs per area of stream should decrease as stream size increases. My estimates agree with this prediction. 
However, the amount of direct allochthonous entering a stream may also be related to the amount of riparian vegetation adjacent to the stream channel. As mentioned earlier, the Little Tennessee River passes through agricultural land use, which has reduced woody riparian vegetation along the river at some sites. In contrast, low order streams in Coweeta Hydrologic Lab experience minimal anthropogenic disturbances. Thus, direct allochthonous inputs in the sixth and seventh order sections of the Little Tennessee may be low due not only to stream size but also local anthropogenic land use.

Flood inputs of leaves due to flood transport were lower as an annual input than direct allochthonous leaffall. At all sites, flood inputs averaged $38 \mathrm{gAFDM} \mathrm{m}^{-2} \mathrm{y}^{-1}$, which was $32 \%$ of annual allochthonous leaf inputs to the river. This suggests that flood inputs of POM to the river are less important than direct allochthonous leaffall to Little Tennessee River. However, flood leaf inputs were $57 \mathrm{gAFDM} \mathrm{m}^{-2} \mathrm{y}^{-1}$ at sites inundated by the flood, which was $40 \%$ of total annual leaf inputs. Furthermore, two of the inundated sites had greater annual flood leaf inputs than direct leaffall. Cuffney (1988) found that flood inputs to the Ogeechee River were an important source of organic matter and was approximately 5x annual litterfall.

The assumptions made for flood transport, however, overestimated flood inputs. I assumed that $10 \mathrm{~m}$ of forested area on both sides of the river had been inundated. The flood of January 1998 was a rather large flood compared to other floods on record. The flood recurrence interval, which is based on its size relative to other floods, was calculated to be 7-8 y. Furthermore, this flood was the seventh largest flood of 27 floods that have occurred on this river since 1945. Despite the size of the flood, $10 \mathrm{~m}$ on both sides of the river did not flood and there was not always $10 \mathrm{~m}$ of forested riparian area along the Little Tennessee River. In addition, the flood occurred near the peak of floodplain leaf standing crop. Thus, there was a large store of litter on the floodplain available for flood transport. Based on the assumptions of the calculations of flood inputs and the timing of the flood, flood leaf inputs to the river probably represent a maximum in my study. This suggests that flood leaf inputs may be a small source of allochthonous POM for the river. 
According to Vannote et al. (1980), allochthonous inputs should also be a smaller energy input to the river than instream autochthonous production. Net primary production in $5-7^{\text {th }}$ order rivers in the eastern United States averaged 378 gAFDM m ${ }^{-2} \mathrm{y}^{-1}$, ranging from 23 to $1281 \mathrm{gAFDM} \mathrm{m}^{-2} \mathrm{y}^{-1}$ (Webster et al. 1995). In my study, total allochthonous inputs, including flood inputs, were $119 \mathrm{gAFDM} \mathrm{m}^{-2} \mathrm{y}^{-1}$, which is smaller than average autochthonous production for eastern United States streams. Thus, autochthonous instream production is probably a more important energy source than allochthonous litter inputs, which supports the predictions of Vannote et al (1980). In contrast, Cuffney (1988) found that allochthonous POM inputs were more than $7 \mathrm{x}$ primary production in the Ogeechee River, Georgia.

\section{Floodplain Tree Assemblages and POM Dynamics}

Floodplain tree species along the Little Tennessee River were typical of bottomland forests of the southern Appalachian Mountains (Greller 1988). Sycamore and American hornbeam were both dominant species, and black walnut and red maple were common. However, tree assemblages differed among the sites as indicated by correspondence analysis. Ordination axis 1 (Figure 12), roughly corresponded along a successional gradient. Tree species positively correlated with this axis (e.g. red maple, yellow-poplar) were indicative of a mature floodplain forest, whereas black walnut, which was negatively correlated with this axis, is an early successional species. In addition, total number of trees and basal area were negatively correlated with this axis. Sites with small woody riparian strips consistently had fewer trees and lower total basal area than sites with extensive woody riparian development. Thus, sites with little woody riparian vegetation had trees that may be typical of hedgerows or recently abandoned fields whereas sites with extensive woody riparian vegetation had species more typical of mature southern Appalachian forests.

Litterfall and total basal area were negatively correlated with axis 2. This axis was mainly driven by one species, sycamore. Sycamore were rather large in diameter, thus, these trees were important contributors to total basal area. In addition, sycamore was also the most important constituent of leaf inputs by weight to the Little Tennessee River floodplain (Table 2). 
Different tree assemblages will affect the quality of litter on the floodplain, and hence, may also affect the quantity of litter on the floodplain. Sycamore, in particular, had a much slower breakdown rate than the other species measured in this study. Thus, sites with a large percentage of inputs from sycamore will have a higher store of litter on the floodplain throughout the year. Site L2, for example, had the largest annual inputs of sycamore and was predicted by the computer model to have the largest store of leaves. This site also had the greatest amount of sycamore in terms of abundance and basal area. In contrast, black walnut had a rather fast breakdown rate and sites (e.g. L4) consisting mainly of black walnut were predicted to have a low store of POM on the floodplain.

Species in this study also fell at different times, which may temporally affect leaf standing crop. Black walnut fell earlier than all other species and sycamore fell later than other species. Although sites consisting mainly of black walnut ( e.g. L4) were predicted by the computer model to have a large increase in leaf standing earlier than other sites, differences in leaf abscission were minor and confined strictly to autumn. Thus this probably would have a negligible impact on POM standing crop unless a flood occurred during autumn. Nevertheless, species composition may not only affect the quality of litter on the floodplain but also the quantity of litter. 


\section{Conclusions}

Floods have a twofold effect on floodplain POM dynamics. First, in my study, the flood increased the leaf breakdown rates of two species: red maple and black walnut. Second, the flood also caused a lateral movement of POM from the floodplain to the river during the flood via entrainment. Although the floodplain was a net exporter of POM, flood inputs were much smaller than estimated direct allochthonous inputs, despite the fact that estimated flood inputs in my study represented a maximum export of POM from the floodplain. Thus, flood POM inputs probably have a small influence on the energetics of the Little Tennessee River, especially because floods are rather infrequent (1 in 2 years) and of short duration (1-2 days) Total allochthonous inputs including flood inputs were smaller than average NPP of similar sized rivers, which supports the predictions of Vannote et al (1980). Thus, the energetics of the Little Tennessee River is probably governed more by instream autochthonous production and import of POM from upstream sources.

Floods can be either a disturbance or a natural event required to maintain diversity and production depending on the hydrologic regime and stream gradient of the stream. Floodplains are often highly connected to rivers through periodic and predictable flooding, in which floods are natural occurrences that maintain floodplain/river diversity and production (Bayley 1995). Thus, the absence of floods represents a disturbance. On the other hand, floods in high gradient streams are disturbances that cause severe mechanical damage to the stream channel and riparian vegetation. Flooding of the Little Tennessee River, however, probably is neither a disturbance nor a natural event required to maintain diversity and production. Floods are too infrequent and short to establish a great degree of connectivity between the floodplain and river, such that the floodplain is a terrestrial ecosystem rather than a wetland ecosystem. In addition, the floodplain is large enough to displace potential catastrophic effects of flooding on the stream channel.

Anthropogenic disturbances, however, may alter river energetics more than the flood regime. Most large rivers in United States have experienced some degree of anthropogenic disturbances. Recently, much emphasis has been placed on the restoring the floodplain/river connectivity through managed floods (e.g. Rio Grande River, Colorado River). The alteration or removal of riparian vegetation by humans for 
agriculture, however, may have a large effect on stream energetics than river/floodplain connectivity. The floodplain forest of the Little Tennessee River, where it exists, is generally restricted to a thin riparian strip consisting of early successional species. In his travels through the Little Tennessee River watershed, William Bartram (1791) spoke of "towns of the ancients" and the "level rich vale and meadows in front, their planting grounds along the river." Hence, it is evident that the floodplain forest of the Little Tennessee River has experienced a legacy of floodplain agriculture, which has impacted the river for more than 200 years. 


\section{Literature Cited}

Aerts, R. 1997. Climate, leaf litter chemistry and leaf litter decomposition in terrestrial ecosystems: a triangular relationship. Oikos 79:439-449.

Bartram, W. 1791. Travels. In Travels of William Bartram. 1998. UGA Press. Athens, Georgia.

Bayley, P. B. Understanding large river-floodplain ecosystems. 1995. BioScience 45:153-158.

Bell, D. T., F. L. Johnson, and A. R. Gilmore. 1978. Dynamics of litterfall, decomposition, and incorporation in the streamside forest ecosystem. Oikos 30:76-82.

Benfield, E. F., D. R. Jones, and M. F. Patterson. Leaf pack processing in a pastureland stream. Freshwater Biology. 15:113-120.

Benfield, E. F. 1996. Leaf breakdown in stream ecosystems. Pages 579-589 in F. R. Hauer and G. A. Lamberti (editors). Methods in stream ecology. Academic Press, New York.

Benfield, E. F. 1997. Comparisons of litterfall input to streams. Pages 104-108 in J. R. Webster and J. L. Meyer (editors). Stream organic matter budgets. Journal of the North American Benthological Society 16:3-161.

Benfield, E. F., J. R. Webster, J. R. Hutchens, J. L Tank, and P. A. Turner. in press. Organic matter dynamics along a stream-order and elevational gradient in a southern Appalachian stream. Internationale Vereinigung für Theoretische und Angewandte Limnologie.

Bott, T. L., J. T. Brock, C. S. Dunn, R. J. Naiman, R. W. Ovink, and R. C. Peterson. 1985. Benthic community metabolism in four temperate stream systems: an interbiome comparison and evaluation of the river continuum concept. Hydrobiologia $123: 3-45$.

Braun, E. L. 1980. Deciduous forests of eastern North America. Hafner Publishing Company, New York.

Bray, J. R. and E. Gorman. 1964. Litter production in forests of the world. Advances Ecological Research 2:101-157. 
Brinson, M. M. 1977. Decomposition and nutrient exchange of litter in an alluvial swamp forest. Ecology 58:601-609.

Brown, S. 1981. A comparison of the structure, primary production, and transpiration of cypress ecosystems in Florida. Ecological Monographs 51:403-427.

Brown, S., and D. L. Peterson. 1983. Structural characteristics and biomass production of two Illinois bottomland forests. American Midland Naturalist 110:107-117.

Chauvet, E. 1988. Influence of the environment on willow leaf decomposition in the alluvial corridor of the Garonne River. Archiv für Hydrobiologie 112:371-386.

Conner, W. H., and J. W. Day, Jr. 1976. Productivity and composition of a baldcypresswater tupelo site and a bottomland hardwood site in a Louisiana swamp. American Journal of Botany. 63:1354-1364.

Conners, M. E., and R. J. Naiman. 1984. Particulate allochthonous inputs: relationships with stream size in an undisturbed watershed. Canadian Journal of Fisheries and Aquatic Sciences 41:1473-1484.

Cuffney, T.F., and J. B. Wallace. 1987. Leaf litter processing in Coastal Plain streams and floodplains of southeastern Georgia, U.S.A. Archiv für Hydrobiologie Supplement 76:1-24.

Cuffney, T.F. 1988. Input, movement and exchange of organic matter within a subtropical coastal blackwater river-floodplain system. Freshwater Biology 19: 305-320.

Cummins, K.W. 1974. Structure and function of stream ecosystems. BioScience 24: 631-641.

Curtis, J. T., and R. P. McIntosh. 1951. An upland forest continuum in the prairie-forest border region of Wisconsin. Ecology 32:476-496.

Delong, M. D., and M. A. Brusven. 1994. Allochthonous input of organic matter from different riparian habitats of an agriculturally impacted stream. Environmental Management 18:59-71.

Dunne, T., and L. B. Leopold. 1964. Water in Environmental Planning. W.H. Freeman and Company, San Francisco. 
Edwards, R .T., and J .L.. Meyer. 1986. Production and turnover of planktonic bacteria in two subtropical blackwater rivers. Applied and Environmental Microbiology 52:1317-1323.

Edwards, R. T. 1986. Sestonic bacteria as a food source for filtering invertebrates in two southeastern blackwater rivers. Limnology and Oceanography 32:221-234.

Fisher, S. G., and G. E. Likens. 1973. Energy flow in Bear Brook: an integrative approach to stream ecosystem metabolism. Ecological Monographs 43:421-439.

Gassith, A., and A. D. Hasler. 1976. Airborne litterfall as a source of organic matter in lakes. Limnology and Oceanography 21:253-258.

Gomez, M. M., and F. P. Day, Jr. 1982. Litter nutrient content and production in the Great Dismal Swamp. American Journal of Botany 69:1314-1321

Greller, A. M. 1988. Deciduous forest. Pages 288-316 in M. G. Barbour and W. D. Billings (editors). North American terrestrial vegetation. Cambridge University Press, New York.

Grubaugh, J. W., and R. V. Anderson. 1989. Upper Mississippi River: seasonal and floodplain forest influences on organic matter transport. Hydrobiologia 174:235244.

Gurtz, M. E., and C. M. Tate. 1988. Hydrologic influences of leaf decomposition in a channel and adjacent bank of a gallery forest stream. American Midland Naturalist 120:11-21.

Hauer, F. H., N. L. Poff, and P. L. Firth. 1986. Leaf litter decomposition across broad thermal gradients in southeastern coastal plain streams and swamps. Journal of Freshwater Ecology 3:545-552.

Hill, B. H. 1981. Organic matter inputs to stream ecosystems: contributions of aquatic macrophytes to the New River. Dissertation, Virginia Polytechnic Institute and State University, Blacksburg, Virginia.

Jones, J. B., and L. S. Smock. 1991. Transport and retention of particulate organic matter in two low-gradient headwater streams. Journal of the North American Benthological Society 10:115-126. 
Junk, W. J., P. B. Bayley, and R. E. Sparks. 1989. The flood pulse concept in riverfloodplain ecosystems. Canadian Special Publication of Fisheries and Aquatic Sciences 106:110-127.

Lamberti, G. A., and A. D. Steinman. 1997. A comparison of primary production in stream ecosystems. Pages 95-104 in J. R. Webster and J. L. Meyer (editors), Stream Organic Matter Budgets. Journal of the North American Benthological Society 16: 3-161.

Malanson, G. P., and J. A. Kupfer. 1993. Simulated fate of leaf litter and large woody debris at a riparian cutbank. Canadian Journal of Forest Research 23:582-590.

McArthur, J. V., J. M. Aho, R. B. Rader, and G. L. Mills. 1994. Interspecific leaf interactions during decomposition in aquatic and floodplain ecosystems. Journal of the North American Benthological Society 13:57-67.

McDowell, W. H., and Fisher, S. G. 1976. Autumnal processing of dissolved organic matter in a small woodland stream ecosystem. Ecology 57:561-569.

McPherson, G. R., and H. A. Wright. 1990. Effects of cattle grazing and Juniperus pinchotii canopy cover on herb cover and production in western Texas. American Midland Naturalist 123:144-151.

Megonigal, J. P., W. H. Conner, S. Kroeger, and R. R. Sharitz. 1997. Aboveground production in southeastern floodplain forests: a test of the subsidy-stress hypothesis. Ecology 78:370-384.

Merrit, R. W., and D. L. Lawson. 1979. Leaf litter processing in floodplain and stream communities. Pages 93-105 in R. R. Johnson and J. F. McCormick (editors). Strategies for protection and management of floodplain wetlands and other riparian ecosystems. USDA Forest Service, Washington, D. C.

Merrit, R. W., and D. L. Lawson. 1992. The role of leaf litter macroinvertebrates in stream-floodplain dynamics. Hydrobiologia 248:65-77.

Mitsch, W. J., and W. G. Rust. 1984. Tree growth responses to flooding in a bottomland forest in northeastern Illinois. Forest Science 30:499-510.

Molles, M. C., Jr., C. S. Crawford, and L. M. Ellis. 1995. Effects of an experimental flood on litter dynamics in the middle Rio Grande riparian ecosystem. Regulated Rivers: Research and Management 11:275-281. 
Mulholland, P. J. 1981. Organic carbon flow in a swamp-stream ecosystem. Ecological Monographs 51:307-322.

Naiman, R. J. 1983. The annual pattern and spatial distribution of aquatic oxygen metabolism in boreal watersheds. Ecological Monographs 53:73-94.

Pederson, N. A., R. H. Jones, and R. R. Sharitz. Age structure and possible origins of old Pinus Taeda stands in a floodplain forest. Journal of the Torrey Botanical Society 124:111-123.

Peterson, D. L., and G. L. Rolfe. 1982. Nutrient dynamics of herbaceous vegetation in upland and floodplain forest communities. American Midland Naturalist 107:325-339.

Peterson, D. L., and G. L. Rolfe. 1982. Nutrient dynamics and decomposition of litterfall in floodplain and upland forests of central Illinois. Forest Science 28:667-681.

Radford, A. E., H. E. Ahles, and C. R. Bell. 1968. Manual of the vascular flora of the carolinas. University of North Carolina Press, Chapel Hill, NC.

Schacht, W. H., J. W. Long, and J. C. Malecheck. 1988. Above-ground production in cleared and thinned stands of semiarid tropical woodland, Brazil. Forest Ecology and Management 23:201-214.

Shure, D. J., and M. R. Gottschalk. Litter-fall patterns within a floodplain forest. American Midland Naturalist 114:98-111.

Shure, D. J., M. R. Gottschalk, and K. A. Parsons. 1986. Litter decomposition processes in a floodplain forest. American Midland Naturalist 115:314-327.

Smock, L. A., 1990. Spatial and temporal variation in organic matter storage in lowgradient, headwater streams. Archiv für Hydrobiologie 118:169-184.

Swank, W. T., and J. B Waide. Characterization of baseline precipitation and stream chemistry and nutrient budgets for control watersheds. Pages 57-80 in W. T. Swank and D. A. Crossley, Jr. (editors). Forest hydrology and ecology at Coweeta. Springer-Verlag, New York. 
Tockner, K., D. Pennetzdorfer, N. Reiner, F. Schiemer, and J. V. Ward. 1999. Hydrological connectivity, and the exchange of organic matter and nutrients in a dynamic river-floodplain system (Danube, Austria). Freshwater Biology 41:521535.

Vankat, J. L. 1979. The natural vegetation of North America. John Wiley and Sons, New York.

Vannote, R. L., G. W. Minshall, K. W. Cummins, J. R. Sedell, and C. E. Cushing, 1980. The river continuum concept. Canadian Journal of Fisheries and Aquatic Sciences 37:130-137.

Wear, D. N., and P. Bolstad. 1998. Land-use changes in southern Appalachian landscapes: spatial analysis and forecast evaluation. Ecosystems 1:575-594.

Webster, J. R. 1977. Large particulate organic matter processing in stream ecosystems. Pages 505-526 in D. L. Correll (editor), Watershed Research in Eastern North America. Smithsonian, Edgewater, Maryland.

Webster, J. R. and Waide, J. B. 1982. Effects of forest clearcutting on leaf breakdown in a southern Appalachian stream. Freshwater Biology 12:331-344.

Webster, J. R., and E. F. Benfield. 1986. Vascular plant breakdown in freshwater ecosystems. Annual Review of Ecology and Systematics 17:567-594.

Webster, J. R., S. W. Golladay, E. F. Benfield, D. J. D’Angelo, and G. T. Peters, 1990. Effects of forest disturbance on particulate organic matter budgets of small streams. Journal of the North American Benthological Society 9:120-140.

Webster, J. R., J. B. Wallace, and E. F. Benfield. 1995. Organic processes in streams of the eastern United States. Pages 117-187 in C. E. Cushing, K. W. Cummins, and G. W. Minshall (editors). Ecosystems of the World 22: River and Stream Ecosystems. Elsevier, New York.

Webster, J. R. and J. L. Meyer. 1997. Organic matter budgets for streams: a synthesis. Pages 104-108 in J. R. Webster and J. L. Meyer (editors). Stream Organic Matter Budgets. Journal of the North American Benthological Society 16:3-161. 
Appendix A: Leaf inputs of woody species to the Little Tennessee River floodplain from Sep 1997 to Dec 1997. Species are ordered by weight in $\mathrm{gAFDM} / \mathrm{m}^{2}$. Values are site means.

\begin{tabular}{|c|c|c|c|c|c|c|c|c|c|c|c|c|c|c|}
\hline \multirow[b]{2}{*}{ Tree Species } & \multicolumn{14}{|c|}{ Site } \\
\hline & U1 & $\mathbf{U} 2$ & $\mathbf{U 3}$ & U4 & U5 & $\mathbf{L 1}$ & $\mathbf{L} 2$ & $\mathbf{L 3}$ & $\mathbf{L 4}$ & $\mathbf{L 5}$ & L6 & L7 & Mean & $\begin{array}{l}\% \text { of } \\
\text { Total }\end{array}$ \\
\hline Platanus occidentalis & 46.2 & 24.7 & 1.3 & 53.1 & 30.9 & 152.7 & 18.9 & 72.8 & 45.1 & 0.6 & 13.8 & 88.1 & 45.7 & 16.6 \\
\hline Carpinus caroliniana & 47.3 & 57.2 & 90.9 & 102.0 & 0.1 & 2.7 & 54.9 & 80.9 & 0.1 & 4.0 & 66.4 & 10.5 & 43.1 & 15.6 \\
\hline Juglans nigra & 26.4 & 42.6 & 8.2 & 5.4 & 71.7 & 0.2 & 1.6 & 7.2 & 204.5 & 0.0 & 0.2 & 41.1 & 34.1 & 12.4 \\
\hline Misc. leaves & 36.9 & 17.3 & 13.4 & 19.3 & 33.0 & 45.3 & 47.2 & 35.9 & 15.9 & 17.9 & 24.7 & 56.2 & 30.2 & 11.0 \\
\hline Acer rubrum & 2.6 & 0.0 & 0.9 & 89.3 & 7.6 & 0.1 & 60.9 & 87.8 & 0.0 & 2.0 & 98.3 & 1.4 & 29.2 & 10.6 \\
\hline Carya sp. & 0.0 & 0.0 & 0.0 & 0.0 & 8.4 & 0.0 & 61.0 & 0.0 & 0.0 & 141.7 & 0.0 & 0.0 & 17.6 & 6.4 \\
\hline Halesia carolina & 30.9 & 0.1 & 0.0 & 5.8 & 0.0 & 0.0 & 65.9 & 4.7 & 0.0 & 5.2 & 8.0 & 63.4 & 15.3 & 5.6 \\
\hline Liriodendron tulipfera & 2.2 & 0.0 & 0.5 & 25.0 & 0.4 & 0.0 & 62.1 & 0.0 & 0.0 & 0.2 & 45.9 & 0.1 & 11.4 & 4.1 \\
\hline Prunus serotina & 22.9 & 2.3 & 4.4 & 0.0 & 19.0 & 0.0 & 21.1 & 15.4 & 1.2 & 0.0 & 0.0 & 20.5 & 8.9 & 3.2 \\
\hline Quercus alba & 0.0 & 0.1 & 0.0 & 0.0 & 0.0 & 0.0 & 0.0 & 0.0 & 0.0 & 0.5 & 81.3 & 0.0 & 6.8 & 2.5 \\
\hline Nyssa sylvatica & 39.4 & 0.7 & 0.1 & 0.5 & 0.0 & 0.0 & 0.5 & 0.1 & 0.0 & 0.0 & 31.5 & 0.0 & 6.1 & 2.2 \\
\hline Parthenocissus quinquefolia & 0.7 & 0.0 & 3.9 & 2.7 & 2.6 & 13.5 & 6.0 & 1.0 & 0.7 & 0.0 & 3.6 & 4.2 & 3.3 & 1.2 \\
\hline Gleditsia triacanthos & 0.0 & 0.0 & 0.0 & 0.0 & 0.0 & 0.0 & 0.0 & 0.0 & 0.0 & 0.0 & 0.0 & 33.6 & 2.8 & 1.0 \\
\hline Cornus sp. & 0.1 & 2.1 & 0.0 & 0.3 & 3.9 & 19.0 & 0.1 & 0.0 & 0.0 & 0.0 & 0.1 & 2.3 & 2.3 & 0.8 \\
\hline Smilax sp. & 2.6 & 0.0 & 0.0 & 1.1 & 8.0 & 0.0 & 2.5 & 3.9 & 0.0 & 2.9 & 1.0 & 1.2 & 1.9 & 0.7 \\
\hline Diospyros virginiana & 0.0 & 0.0 & 0.8 & 0.0 & 0.0 & 0.0 & 0.0 & 0.2 & 0.0 & 13.5 & 2.5 & 2.5 & 1.6 & 0.6 \\
\hline Asimina triloba & 0.0 & 0.0 & 0.0 & 18.2 & 0.0 & 0.0 & 0.0 & 0.0 & 0.0 & 0.0 & 0.1 & 0.0 & 1.5 & 0.6 \\
\hline Kalmia latifolia & 0.0 & 0.0 & 0.0 & 0.0 & 0.0 & 0.0 & 0.0 & 0.0 & 0.0 & 15.5 & 0.8 & 1.3 & 1.5 & 0.5 \\
\hline Salix nigra & 0.0 & 0.0 & 0.0 & 0.0 & 0.0 & 14.8 & 0.0 & 0.0 & 0.0 & 0.0 & 2.7 & 0.1 & 1.5 & 0.5 \\
\hline Pyrularia pubera & 0.0 & 0.0 & 0.0 & 0.0 & 0.0 & 0.0 & 16.7 & 0.0 & 0.0 & 0.0 & 0.0 & 0.0 & 1.4 & 0.5 \\
\hline Calycanthus floridus & 0.0 & 0.0 & 0.0 & 0.0 & 0.0 & 0.0 & 0.0 & 0.0 & 0.0 & 16.1 & 0.1 & 0.0 & 1.4 & 0.5 \\
\hline Corylus americana & 0.0 & 0.0 & 0.0 & 0.0 & 0.0 & 6.7 & 0.0 & 0.0 & 0.0 & 0.0 & 0.0 & 7.1 & 1.1 & 0.4 \\
\hline Robinia pseudoacacia & 4.4 & 0.0 & 0.5 & 0.0 & 0.0 & 4.4 & 2.7 & 0.0 & 0.0 & 0.6 & 1.0 & 0.1 & 1.1 & 0.4 \\
\hline Celtis laevigata & 0.0 & 0.0 & 0.0 & 0.0 & 0.0 & 0.0 & 0.0 & 12.7 & 0.0 & 0.0 & 0.0 & 0.0 & 1.1 & 0.4 \\
\hline
\end{tabular}




\begin{tabular}{|c|c|c|c|c|c|c|c|c|c|c|c|c|c|c|}
\hline Tree Species & U1 & $\mathbf{U} 2$ & $\mathbf{U 3}$ & $\mathbf{U 4}$ & U5 & $\mathbf{L 1}$ & $\mathbf{L 2}$ & $\mathbf{L 3}$ & L4 & L5 & L6 & L7 & Mean & $\begin{array}{l}\% \text { of } \\
\text { Total }\end{array}$ \\
\hline Quercus rubra & 0.0 & 0.0 & 0.0 & 0.0 & 0.0 & 0.0 & 0.6 & 0.0 & 0.2 & 8.6 & 1.4 & 0.1 & 0.9 & 0.3 \\
\hline Rhus radicans & 0.5 & 1.5 & 1.6 & 0.0 & 0.0 & 0.0 & 1.9 & 0.6 & 0.0 & 0.0 & 0.0 & 4.5 & 0.9 & 0.3 \\
\hline Castanea sp. & 0.0 & 0.0 & 0.0 & 0.0 & 0.0 & 0.0 & 0.0 & 0.0 & 0.0 & 0.0 & 0.0 & 7.8 & 0.6 & 0.2 \\
\hline Juniperus virginiana & 0.0 & 0.0 & 0.0 & 0.0 & 0.0 & 0.0 & 0.0 & 7.0 & 0.0 & 0.0 & 0.0 & 0.0 & 0.6 & 0.2 \\
\hline Ligustrum sp. & 0.0 & 5.0 & 0.0 & 0.0 & 0.0 & 0.0 & 0.0 & 0.0 & 0.0 & 0.0 & 0.0 & 0.0 & 0.4 & 0.2 \\
\hline Rhododendron sp. & 0.0 & 0.0 & 0.0 & 0.0 & 0.0 & 0.0 & 0.0 & 0.0 & 0.0 & 0.0 & 4.7 & 0.0 & 0.4 & 0.1 \\
\hline Lindera benzoin & 0.0 & 0.0 & 0.0 & 0.0 & 0.0 & 0.0 & 0.0 & 4.4 & 0.0 & 0.0 & 0.0 & 0.0 & 0.4 & 0.1 \\
\hline Ilex decidua & 0.0 & 0.0 & 0.0 & 0.0 & 0.0 & 0.0 & 0.0 & 0.0 & 0.0 & 3.9 & 0.0 & 0.0 & 0.3 & 0.1 \\
\hline Cornus florida & 0.0 & 0.0 & 0.0 & 0.0 & 1.2 & 0.0 & 0.0 & 0.0 & 0.0 & 0.0 & 0.0 & 0.0 & 0.1 & 0.0 \\
\hline Symplocos tinctoria & 0.0 & 0.0 & 0.0 & 0.0 & 0.0 & 0.0 & 0.0 & 0.0 & 0.0 & 0.0 & 0.8 & 0.0 & 0.1 & 0.0 \\
\hline Pinus virginiana & 0.0 & 0.0 & 0.0 & 0.0 & 0.0 & 0.0 & 0.1 & 0.0 & 0.0 & 0.2 & 0.0 & 0.0 & 0.0 & 0.0 \\
\hline Fagus grandifolia & 0.0 & 0.0 & 0.0 & 0.1 & 0.0 & 0.0 & 0.0 & 0.0 & 0.0 & 0.0 & 0.0 & 0.0 & 0.0 & 0.0 \\
\hline Sassafras albinum & 0.0 & 0.0 & 0.0 & 0.0 & 0.0 & 0.0 & 0.0 & 0.0 & 0.0 & 0.0 & 0.0 & 0.0 & 0.0 & 0.0 \\
\hline
\end{tabular}


Appendix B: Basal area, density, and importance values (relative basal area + relative density) of tree species (stems $\geq 2 \mathrm{~cm} \mathrm{DBH}$ ) on the floodplain of the Little Tennessee River floodplain.

\begin{tabular}{|c|c|c|c|}
\hline Tree Species & $\begin{array}{c}\text { Basal Area } \\
\left(\mathbf{m}^{2} / \mathbf{h a}\right)\end{array}$ & $\begin{array}{c}\text { Density } \\
\text { (\# of trees/ha) }\end{array}$ & IV \\
\hline Platanus occidentalis & 8.224 & 20.8 & 43.7 \\
\hline Carpinus caroliniana & 2.110 & 57.1 & 29.1 \\
\hline Carya glabra & 2.110 & 22.5 & 17.1 \\
\hline Acer rubrum & 2.524 & 15.8 & 16.7 \\
\hline Juglans nigra & 1.174 & 30.0 & 15.6 \\
\hline Liriodendron tulipfera & 2.209 & 10.8 & 13.6 \\
\hline Halesia caroliniana & 0.744 & 17.1 & 9.2 \\
\hline Cornus sp. & 0.149 & 21.3 & 8.0 \\
\hline Prunus serotina & 0.549 & 15.0 & 7.6 \\
\hline Calycanthus floridus & 0.134 & 20.0 & 7.5 \\
\hline Robinia pseudoacacia & 0.777 & 5.4 & 5.3 \\
\hline Salix nigra & 0.413 & 7.1 & 4.3 \\
\hline Asimina triloba & 0.035 & 11.3 & 4.0 \\
\hline Diospyros virginiana & 0.057 & 5.0 & 2.0 \\
\hline Pyrularia pubera & 0.014 & 5.0 & 1.8 \\
\hline Nyssa sylvatica & 0.133 & 2.5 & 1.5 \\
\hline Quercus rubra & 0.182 & 1.7 & 1.4 \\
\hline Lindera benzoin & 0.160 & 1.7 & 1.3 \\
\hline Quercus alba & 0.256 & 0.4 & 1.3 \\
\hline Ilex opaca & 0.007 & 3.3 & 1.2 \\
\hline Castanea & 0.213 & 0.4 & 1.1 \\
\hline Gleditsia triacanthos & 0.101 & 1.7 & 1.0 \\
\hline Kalmia latifolia & 0.005 & 2.5 & 0.9 \\
\hline Pinus virginiana & 0.121 & 0.8 & 0.8 \\
\hline Catalpa bignonioides & 0.037 & 1.3 & 0.6 \\
\hline Ligustrum sp. & 0.003 & 1.7 & 0.6 \\
\hline Sassafra albidum & 0.001 & 1.7 & 0.6 \\
\hline Corylus americaner & 0.017 & 0.8 & 0.4 \\
\hline Celtis laevigata & 0.016 & 0.8 & 0.4 \\
\hline Cercis canadensis & 0.008 & 0.8 & 0.3 \\
\hline Juniperus virginiana & 0.029 & 0.4 & 0.3 \\
\hline Hamamelis virginiana & 0.006 & 0.4 & 0.2 \\
\hline Tilia americana & 0.004 & 0.4 & 0.2 \\
\hline Cornus florida & 0.004 & 0.4 & 0.2 \\
\hline Fraxinus pennsylvanica & 0.003 & 0.4 & 0.2 \\
\hline Symplocos tinctoria & 0.000 & 0.4 & 0.1 \\
\hline Rhus typhina & 0.000 & 0.4 & 0.1 \\
\hline Ilex decidua & 0.000 & 0.0 & 0.0 \\
\hline Total & 22.5 & 289.2 & 200.0 \\
\hline
\end{tabular}




\section{MATTHEW A. NEATROUR CURRICULUM VITAE}

Present Address: Department of Biology

Virginia Polytechnic Institute and State University

Blacksburg, VA 24061-0406

DATE AND PLACE OF BIRTH: 15 October 1973: Johnstown, Pennsylvania

EDUCATION:

Virginia Polytechnic Institute and State University, Blacksburg, VA, M.S. Degree in Biology, 1996

Bucknell University, Lewisburg, PA, B.A. Degree in Biology; 1996, magna cum laude

\section{RESEARCH EXPERIENCE:}

Recovery of Aquatic Insect Communities Following Attempts to Neutralize Acid Mine Drainage. Senior Honors Thesis, Bucknell University:

Fall and Spring 1995-1996, Dr.W. McDiffett, advisor.

Katherine Mabis McKenna Summer Internship. Measured water chemistry

characteristics and assembled a taxonomic list for a stream that had been affected by acid mine drainage, Bucknell University: Summer 1995,

Dr. W. McDiffett, advisor.

Graduate Research Assistant. Organized field experiments, conducted laboratory experiments, and managed processing laboratory, Virginia Polytechnic Institute and State University: Stream Ecology Laboratory, January 1998-present, Dr. J.R. Webster, advisor.

\section{PROFESSIONAL EXPERIENCE:}

Graduate Teaching Assistant, Virginia Polytechnic Institute and State University: General Biology Laboratory, August 1996-December 1998.

\section{GRANTS:}

Graduate Research Development Program, Virginia Polytechnic Institute and State University, July 1998, \$300. 


\section{PROFESSIONAL PRESENTATIONS:}

Neatrour, M.A., J.R. Webster, and E.F. Benfield. 1998. The role of floods in the exchange of particulate organic matter between a southern Appalachian stream and its floodplain. 1998 All Coweeta meeting. Athens, GA. (presented by M.A.

Neatrour).

Neatrour, M.A. 1999. Floods and organic matter dynamics in a river/floodplain ecosystem. Virginia Tech ecology/evolution biology seminar. Blacksburg, VA. (presented by M.A. Neatrour).

Neatrour, M.A., J.R. Webster, and E.F. Benfield. 1999. The role of floods in the exchange of particulate organic matter between a southern Appalachian stream and its floodplain. 1999 North American Bentholigical Society meeting . Duluth, MN. (presented by M.A. Neatrour).

Neatrour, M.A., J.R. Webster, and E.F. Benfield. 1999. The role of floods in the exchange of particulate organic matter between a southern Appalachian stream and its floodplain. 1999 NSF review of Coweeta LTER site. Duluth, MN. (presented by M.A. Neatrour).

PROFESSIONAL MEMBERSHIP:

North American Benthological Society

\section{HONORS AND AWARDS:}

1999 North American Benthological Society student travel award Sparks Memorial Award for the Highest G.P.A. in the Chi Phi Fraternity Phi Beta Kappa

Phi Sigma Biological Honor Society 